\title{
Sea-level control on turbidite activity in the Rhone canyon and the upper fan during the Last Glacial Maximum and early Deglacial
}

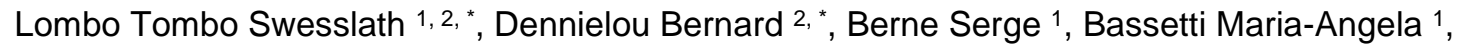 \\ Toucanne Samuel 2, Jorry Stephan 2, Jouet Gwenael 2, Fontanier Christophe ${ }^{2}$
}

1 Univ Perpignan, CEFREM UMR 5110, F-66860 Perpignan, France.

2 IFREMER, UR Geosci Marines, Lab Environm Sedimentaires, F-29280 Plouzane, France.

* Corresponding authors : S. Lombo Tombo, email address : Swesslath.Lombo.Tombo@ifremer.fr ; B. Dennielou, email address : BemardDennielou@ifremer.fr

\begin{abstract}
:
The timing, routing and processes of sediment transfer from the continents to the oceans at millennial time-scale are still largely unknown. The potential of turbidite systems (dominantly deposited during sealevel lowstands) to record global or regional environmental fluctuations is usually under-exploited because of the difficulty to obtain robust chronostratigraphic constraints in turbiditic deposits, and therefore to tie changes in sedimentary processes to environmental fluctuations. We were able to obtain a millennialscale chronostratigraphy based on oxygen isotopes of the scarce foraminifera preserved in turbiditic deposits of the Rhone Turbidite System within the Western Mediterranean. Our results show that 1) objective criteria can be defined for the selection of foraminifera preserved within the pelagic intervals between the turbiditic sequences, in order to obtain a reliable isotope stratigraphy; 2) Turbidites triggered by hyperpycnal currents are described for the first time within the Rhone Turbidite System. They are related to the periods of direct fluvial connection with the canyon head (during the sea-level lowstand and early rise), and to a period of high sediment flux in relation with the massive recession of the Rhone glaciers in the Alps; 3) The lithofacies change passing from hyperpycnal to "Bouma-type" is dated at ca 19 cal. ka BP, which might correspond to an acceleration of sea-level rise (19-ka Meltwater Pulse,).
\end{abstract}

Keywords : Rhone Turbidite System, Turbidites, Hyperpycnite, Sea level, Last Glacial Maximum, Western Mediterranean 


\section{Introduction}

It is commonly accepted that most of the detrital sediments are transferred to the deep-sea during sealevel lowstands, accumulating along the continental slope and rise as gravity deposits, especially in the form of turbidites (Posamentier and Vail, 1988). However, the precise timing, as well as the processes that control these transfers, are still largely unknown or constitute matter for debate (Allen, 2008; Castelltort and Van Den Driessche, 2003; Covault and Graham, 2010). The influence of climate and environmental changes on the nature of turbidites has been recognized (Bouma, 2001), but in return, these deposits are considered unusable for paleoceanographic and paleoclimatic reconstructions because they are, by definition, made of reworked material. Some studies, however, have shown that the hemipelagic sediments interbedded within turbiditic series can provide valuable and very expanded archives of past climate changes (Bonneau et al., 2014; Bourget et al., 2010; Henrich et al., 2010; Jorry et al., 2011; Lebreiro et al., 2009; Nakajima and Itaki, 2007; Pierau et al., 2010; Pouderoux et al., 2012; Toucanne et al., 2008). The quality of the results relies on the capacity to distinguish hemipelagic from turbiditic beds, and on the presence of a pelagic component (commonly biogenic carbonates) to obtain chronostratigraphic constraints based on radiocarbon dating, oxygen isotopes, or microfaunal assemblages.

In this paper, we establish a precise chrono-stratigraphic framework of the Rhone Turbidite System, western Mediterranean Sea, during the Last Glacial Maximum (LGM) and early Deglacial. 
This enables us 1) to quantify fluctuations in the sediment accumulation rates, 2) to characterize the sedimentary processes that have controlled the fluctuations of turbiditic overbank processes 3) to link the functioning of the Rhone Turbidite System to sea-level fluctuations and to climate changes in the Mediterranean area.

\section{Study area: general framework and previous work}

\subsection{The Gulf of Lions continental margin}

The Gulf of Lions is a young (23 Myr, Aquitanian) passive margin constituting the north-western part of the Mediterranean Sea (Le Pichon et al., 1971). It comprises a relatively large $(50-70 \mathrm{~km})$ continental shelf, with the shelf break being situated at water depths ranging from 120 to $170 \mathrm{~m}$. The continental slope is incised by several canyons, up to $1000 \mathrm{~m}$ deep (Berne et al., 1998) (Fig. 1). The source of sediments is dominated by the Rhone River and outlined by the large delta that composes nearly $1 / 3$ of the coast of the Gulf of Lions (L'homer et al., 1981; Vella et al., 2005). In addition, the general anti-clockwise circulation in the Gulf of Lions has contributed to the westwards development of an elongated mud belt on the mid-shelf (Berné et al., 2007; Fanget et al., 2013). Along the shelf edge, modern hydrodynamic processes are dominated by wind-driven circulation (Ulses et al., 2008) and dense water cascades (Canals et al., 2006) that rework relict sand bodies at the shelf edge and contribute to the export of sediment through the canyon and onto the base of slope (Bassetti et al., 2006; Canals et al., 2006; Dennielou et al., 2009; Gaudin et al., 2006a; Palanques et al., 2006).

At the base of slope, two large sedimentary bodies, the Rhone Turbidite System and the PyreneoLanguedocian Sedimentary Ridge have dominantly developed during the Plio-Quaternary highfrequency glacio-eustatic fluctuations (dos Reis et al., 2005; Droz et al., 2006). They belong to the Lowstand Systems Tracts of fourth-order glacio-eustatic cycles in the early "Exxon" model of sequence stratigraphy (Posamentier and Vail, 1988). 


\subsection{Morphology and structure of the Rhone Turbidite System}

The Rhone turbidite system is the largest sediment body in the western Mediterranean. It is a thick (3 $600 \mathrm{~m}$ ) accumulation of sediments from the base of the slope down to the Balearic Abyssal Plain at water depths up to $2850 \mathrm{~m}$. The early development of the Rhone Turbidite System, during the Pliocene (dos Reis et al., 2005; Droz et al., 1991), identified as the Rhone Basal Complex (Droz et al., 2006) followed the re-flooding of the Mediterranean after the Messinian Salinity Crisis (Bache et al., 2012; Clauzon, 1973; Hsü and Ryan, 1973; Lofi et al., 2003). In the distal domain, the radial channel network connects the Rhone Turbidite System to the Petit-Rhone canyon (Jegou, 2008). This morphology characterizes dominantly muddy sediment sources, as is the case for the Amazon fan (Flood et al., 1991; Pirmez and Flood, 1995), the Bengal Fan (Curray et al., 2002) and the Indus fan (Kolla and Coumes, 1987).

Our study is focused on the canyon and upper fan initially described by Droz (1983). This will be illustrated through recent bathymetric data (Figs. 2 and 3) acquired during the Rhosos (RHOne SOurce to Sink) cruise (2008).

The Petit-Rhone canyon is, at mid-slope, about $12.6 \mathrm{~km}$ wide and $500 \mathrm{~m}$ deep. In its upper part (between 500 and 1350 water depths) the canyon has a U-shape with a stepped structure and well-developed internal terraces (Dennielou et al., 2009; Droz, 1983). Similar well-developed terraces have been already described in canyons feeding turbidite systems like the Cap Breton canyon (Cirac et al., 2001), the Cap Timiris Canyon (Antobreh and Krastel, 2006) and the Zaire/Congo canyon (Babonneau et al., 2002). Sedimentary records on the terraces are interpreted as dominantly aggradational and therefore indicate a sedimentary environment favourable for the record of past turbiditic activity (Babonneau et al., 2004; Gaudin et al., 2006b). As in other canyons of the Gulf of Lions (Baztan et al., 2005), a narrow meandering axial incision is observed in the canyon, but it only starts beyond the $300 \mathrm{~m}$ depth contour line (compared to 120 to $200 \mathrm{~m}$ for other canyon heads). 
The upper fan, between $1350 \mathrm{~m}$ and $2000 \mathrm{~m}$ water depths, displays a perched valley, 12 to $4 \mathrm{~km}$ wide and 500 to $200 \mathrm{~m}$ deep, that progressively decreases in depth and width in the seaward direction (Droz, 1983; Fanget, 2009; Torres et al., 1997). The valley is cut by an axial meandering, called thalweg, between 1000 and $600 \mathrm{~m}$ wide and 150 to $100 \mathrm{~m}$ deep. Locally the thalweg shows very tight meanders that are cuspate shaped, with radii less than $250 \mathrm{~m}$ (Fanget, 2009; O'Connell et al., 1991).

\subsection{Chrono-stratigraphic framework}

Most of the chrono-stratigraphic constraints available in the Gulf of Lions for the last $30 \mathrm{kyr}$ were obtained on sediment cores from the continental shelf (Aloïsi, 1986; Bassetti et al., 2008; Bassetti et al., 2006; Berné et al., 2007; Fanget et al., 2014; Jouet, 2007; Jouet et al., 2006) and the upper slope (Sierro et al., 2009). On the outer shelf, upper Pleistocene deposits are organized as prograding wedges bounded by discontinuities (Rabineau et al., 2006; Tesson et al., 1990). They are interpreted as forced-regressed deposits while transgressive deposits are limited to a thin veneer of reworked sands that top the regressive shoreface deposits (Bassetti et al., 2006; Berne et al., 1998; Jouet et al., 2006). Therefore, most of the outer shelf is covered by a condensed interval, most of the Deglacial sediments being found on the middle shelf, with a Younger Dryas transgressive parasequence remaining at depths between 40 and 60 m (Berné et al., 2007). Finally, the late Holocene Highstand Systems Tract is confined to the inner shelf where it reaches up to $50 \mathrm{~m}$ in thickness in the vicinity of the present Rhone delta coastline (Gensous et al., 2009).

At the base of slope, very few chronological constraints exist on the Rhone Turbidite System or on the Pyreneo-Languedocian Sedimentary Ridge for the Late Pleistocene. On the Rhone Turbidite System the post-glacial period is recorded by the end of the turbiditic activity and dated at $15,510 \pm 50{ }^{14} \mathrm{C}$ years ( 18 cal. ka BP) (Bonnel et al., 2005; Dennielou et al., 2009). Pollen and dynocists assemblages determined in the turbiditic facies allowed to assign a maximum age of ca. 30 cal. ka BP for turbidites situated 10 m below sea-floor (Beaudouin et al., 2004). 
On the Pyreneo-Languedocian Sedimentary Ridge, core MD99-2346 retrieved at $2100 \mathrm{~m}$ water depth covers the last ca. 27 ky (Melki et al., 2009). The oxygen isotope records, as well as planktonic foraminifera assemblages at this site, show that the changes of sea-surface temperature were synchronous with Northern-Hemisphere climate changes (Younger Dryas, Heinrich Stadial 1 and 2, Bolling/Allerod interstadial) (Melki et al., 2009). These proxies may therefore be utilized as chrono-stratigraphic references in the area. Both sites show that the turbiditic activity stopped during the last deglaciation, resulting in a decrease of the sedimentation rate in the order of $80 \%$.

\section{Methods and data}

This study focuses on two Kullenberg piston cores recovered from the Rhone Turbidite System during the RHOSOS cruise (2008, aboard R/V Le Suroit) (Figs. 1 and 3). Core RHS-KS65 was collected on a terrace of the eastern (left) side of the Petit-Rhone Canyon (1010 m water depth), where the canyon is $382 \mathrm{~m}$ deep (Fig. 4a). Core RHS-KS67 was located on the eastern (left) side of the upper-fan valley (1566 m water depth), within the straight, 138 m-deep valley (Fig. 4b). More details about these cores are given in Table 1. Chirp seismic profiles were acquired during the same cruise. The bathymetric compilation combines multi-beam EM300 data acquired during several cruises (MARION 2000; GMO2-CARNAC; 2002; SEEPGOL, 2008; RHOSOS, 2008).

\subsection{Sedimentological approach}

This approach implies the determination of lithofacies based on sediment composition, grain-size, and sedimentary structures. In this paper, we use the term of laminae to describe layers $<1 \mathrm{~mm}$, and bed for those $>1 \mathrm{~mm}$. Lithofacies were determined by using visual description of colour, lithology, primary sedimentary structures, ichnofacies and microfossil content. X-ray photographs (core RHSKS67) were used to better visualize sedimentary structures. Grain-size analyses were performed on bulk sediment with a Coulter LS230 laser micro-granulometer with the primary objective to characterize the turbidites. The sampling strategy was determined by this objective and we focused 
on coarse intervals and on the transition with adjacent muddy interval. The sampling interval in turbiditic beds was in the order $2 \mathrm{~cm}$, and adapted to bed thickness. A quantity of sediment sufficient for a good obscuration (between 8 and $12 \%$ ) has been measured after stirring in distilled water until desegregation was complete.

\subsection{Chronological approach}

In order to establish a chronology framework in the Rhone Turbidite System, both cores were sampled for isotope analyses, ${ }^{14} \mathrm{C}$ AMS dating and foraminifera counting. Samples were collected at ca. $10 \mathrm{~cm}$ interval in the hemipelagic intervals, and at the top of the turbiditic beds/laminae in the turbiditic lithofacies. Sediment samples were dried and sieved with water using a $63 \mu \mathrm{m}$ mesh; residue was dried again.

For oxygen isotope analysis, the samples were dry sieved to retain the size fraction $>200-\mu \mathrm{m}$. 20 tests of Globigerina bulloides were picked for analyses that were performed at the Leibniz Laboratory for Radiometric Dating and Stable Isotope Research of CAU Kiel.

For foraminiferal assemblages analysis, benthic and planktonic foraminifera counting was carried out under a binocular microscope on the size fraction $>150-\mu \mathrm{m}$. The relative abundance of planktonic and benthic foraminifera was determined by counting at least 300 specimens including allochtonous and autochtonous benthic foraminifera (Tabs. A1 and A2). In order to determine the imprint of turbiditic processes on foraminiferal assemblages, four intervals were sampled with 2-cm spacing in core RHS-KS67 (50-75 cm; 220-242 cm; 478-488 cm; 780-796 cm). In these samples, all specimens from the size fraction $>125-\mu \mathrm{m}$ were counted because of the scarcity of foraminifera.

Radiocarbon dating was determined by accelerator mass spectrometry on mono-specific samples of G. bulloides when possible, or on mixed planktonic species. A minimum of $7 \mathrm{mg}$ per sample was collected in the size fraction $>200 \mu \mathrm{m}$. Analyses were carried out at the Laboratoire de Mesure du 
Carbone 14 de Saclay (Sac) and at Poznan Radiocarbon Laboratory (Poznàn) (Tabs. 2 and 3). Conversion into calendar years was obtained with Calib7.01 software and the "Marine 13" calibration curve $(\Delta \mathrm{R}=0)$ (Reimer et al., 2013).

This approach was completed by data from core MD99-2346 collected within the Pyreneolanguedocian sedimentary ridge (Tab. 1), and studied by Melki et al (2009). In this core, the age model is based on 13 radiocarbon dating for the interval 0-28 cal. ka BP. In order to be consistent with recent radiocarbon calibration, these dates were recalibrated using the Calib7.01 software and the "Marine 13" calibration curve $(\Delta \mathrm{R}=0)$ (Reimer et al., 2013).

In order to quantify the turbiditic activity of the Rhone Turbidite System, turbiditic beds/laminae were counted and characterized by their grain-size (median) and thickness. Counts were converted into frequencies of occurrence at 250-year intervals.

\section{Results}

\subsection{Lithofacies and corresponding sedimentary interpretation}

Up to 7 lithofacies were determined in both studied cores (Figs. 5, 6a and 6b). The details of lithofacies and correspondence to other studies are given in Tab. 4.

Lithofacies 1 (Fig. 6a) corresponds to a bioturbated foraminifera and calcareous nannoplankton ooze. It is found at the top of both cores. Lithofacies 2 (Fig. 6a) corresponds to a bioturbated foraminifera and nannoplankton mud is found below lithofacies 1 in both cores.

Lithofacies 3 (Fig. 6a) corresponds to a laminated terrigeneous mud. In core RHS-KS65 laminations consist of hydrotroilite (black specks) -rich laminae. In core RHS-KS67, laminae are silty and suggest that small size turbiditic overflows occurred in the upper-fan valley.

Lithofacies 4 (Figs. 6a and 6b) is found only in the upper-fan valley (RHS-KS67) and corresponds to thinning and fining upward silty beds (up to $7 \mathrm{~cm}$ thick) evolving to silty laminae, 
intercalated with homogeneous grey mud. The silty beds frequently display a normal grading and, sometimes, an erosional basis. Four sub-facies can be distinguished on the basis of bed/laminae thickness and grading. Lithofacies $4 \mathrm{a}$ to $4 \mathrm{c}$ (Fig. 6a), characterized by thinning and fining upward silty beds (up to $3 \mathrm{~cm}$ thick) with a normal grading. Lithofacies $4 \mathrm{~d}$ (Fig. 6b) is characterized by thick silty beds (up to $3 \mathrm{~cm}$ ) among which some of them show a distinct reverse grading at the base changing to normal grading at the top (Fig. 6b).

Lithofacies 1 and 2 are interpreted as dominantly pelagic. The lithofacies 3 is interpreted as hemipelagic with terrigenous pulses as indicated by the high sedimentation rate (up to $100 \mathrm{~cm} \cdot \mathrm{kyr}^{-1}$ ) and by the occurrence of discontinuous laminae of hydrotroillite that would have been generated by organic matter input from continental origin. A similar laminated facies in the Bay of Biscay has been interpreted as the result of large terrigenous supplies, possibly triggered by the cascading of nepheloid layers and driven by seasonal sedimentary discharges from the rivers (Zaragosi et al., 2006). Lithofacies 4 (a, b, c and d) is interpreted as turbidites resulting from the overflow of sediment-laden density currents (turbidity currents) from the narrow thalweg. Lithofacies $4 \mathrm{a}$ to $4 \mathrm{c}$, characterized by fining upward (Fig. 6a), are interpreted as fine-grained turbidites probably triggered by intra-canyon sediment failures. Lithofacies $4 \mathrm{~d}$ is interpreted as turbidites triggered by the sinking of a hyperpycnal plume (Mulder and Alexander, 2001), probably in relation with the discharge of the Rhone River (see discussion).

\subsection{Abundance and preservation of foraminifera in the lithofacies}

Planktonic and benthic foraminifera assemblages are determined by trophic and oceanographic conditions. However, the preservation of assemblages is also governed by sedimentary processes, such as turbiditic processes that are able to erode and rework the sediment. The occurrence, preservation and assemblages of planktonic and benthic foraminifera were determined in order to identify suitable samples for chronostratigraphy, and to identify oceanographic changes as those 
determined in core MD99-2346 (Melki et al., 2009). The details of assemblages are given in Tab. 6 and in the Appendices.

In both cores, foraminifer assemblages show characteristics very similar to those observed on core MD99-2346 (Melki et al., 2009). The difference between the end of the MIS (Marine Isotope Stage) 2 and MIS 1, marked by respectively high and low $\partial^{18} \mathrm{O}$ values, is well-recognized by the relative abundance of planktonic species (Fig. 7 and Tabs. A1 and A2). This is comforted by the high abundance of Gyroidina altiformis, a mesotrophic benthic species which was used as an indicator of Holocene benthic conditions (Melki et al., 2009). Thus, the end of MIS 2 (LGM and Heinrich Stadial 1 - HS 1) is characterised by the abundance of G. bulloides while during MIS1 appear Globorotalia inflata, Globigerinoides ruber and G. altiformis.

The most recent interval of the LGM ( $c$ a. 20-18.5 cal. ka BP) is identified between 688 and 645 cm in core RHS-KS65 and, from 797 to $410 \mathrm{~cm}$ in core RHS-KS67 (Fig. 7). It is characterized by the dominance of $G$. bulloides and of the subpolar/polar species Turborotalita quinqueloba and Neogloboquadrina pachyderma. HS 1 is found between 645 and $250 \mathrm{~cm}$ and 410 to $150 \mathrm{~cm}$ respectively in cores RHS-KS65 and RHS-KS67.

Lithofacies 1 is characterized by the high abundance of planktonic species, the presence of Globorotalia inflata, of the subtropical species G. ruber and by the high abundance of the benthic species G. altiformis, a mesotrophic benthic species that was used as an indicator of Holocene benthic conditions (Melki et al., 2009), similar to those of today. It corresponds to the Holocene period, starting at $c a .11 .7 \mathrm{cal}$. ka BP. It is identified in the upper $90 \mathrm{~cm}$ in core RHS-KS65 and in the upper $50 \mathrm{~cm}$ in core RHS-KS67.

Lithofacies 2 is characterized by abundant foraminifera with few fragmented tests (Fig. 8). The planktonic foraminifer assemblage, with $N$. pachyderma and G. bulloides as the most abundant species, is typical of the Deglacial period in the Mediterranean (Blanc-Vernet, 1969; Melki et al., 
2009). Benthic foraminifer assemblage is dominated by autochthonous species (Cibicidoides pachyderma, Chilostomella ovoidea, Melonis barleeanus) and with only few species reworked from the upper slope and shelf settings (Cassidulina laevigata var. varinata) (Fig. A3).

Lithofacies 3 yields less abundant foraminifera and only a few fragmented tests (Fig. 8). The planktonic foraminifer assemblage is similar to that of lithofacies 2 and characteristic of the early stage of the deglaciation in the Mediterranean. Benthic foraminifer assemblages reveal abundant neritic species, which are typical for shelf and upper slope settings (Cibicides lobatulus and Cassidulina laevigata var. varinata), and thus indicate intense reworking of shelf/slope deposits. Reworking is possibly driven by transport in the nepheloid layer during major storm events (Duros et al., 2012). Within lithofacies 3, the quasi-disappearance of the transitional/subtropical species $G$. inflata and G. ruber between 150 to $90 \mathrm{~cm}$ in core RHS-KS65, and 80 to $50 \mathrm{~cm}$ in core RHS-KS67 (Fig. 7) is correlated to the Younger Dryas (12.8-11.7 cal. ka BP). From 250 to $150 \mathrm{~cm}$ in core RHS-KS65 and from 150 to $90 \mathrm{~cm}$ in core RHS-KS67, the sharp decrease of G. bulloides and the appearance of the benthic foraminifera Gyroidina altiformis and of warm planktonic foraminifera species is correlated to The Bølling-Allerød, starting at $c a .14 .7$ cal. ka BP.

In lithofacies $4 \mathrm{~b}$, the muddy intervals contain abundant foraminifera with few fragmented tests (Fig. 8). Planktonic assemblage (Tab. 6 and Fig. A1) dominated by Neogloboquadrina pachyderma Globigerina bulloides and Turborotalia quinqueloba is characteristic of the Glacial period (Melki et al., 2009). Benthic assemblage is dominated by autochtonous species such as Cibicidoides pachyderma, Bolivina spathulata and Chilostomella ovoidea (Fig. A2), suggesting that no reworking by turbiditic processes occurred. The coarse intervals contain few foraminifera with a large amount of fragmented tests. The planktonic assemblage is the same as in the mud but more fragmented. The benthic assemblage is dominated by allochtonous species, among which Siphonaperta aspera (30-50\%) is dominant and indicative of transport by energetic currents. Lithofacies $4 \mathrm{~d}$ shows similar assemblages as lithofacies $4 \mathrm{~b}$ but reworked species are more abundant 
both in the muddy and in the coarse-grained intervals (Figs 8 and A3). Within lithofacies 4, the dominance of $G$. bulloides and of the subpolar/polar species Turborotalita quinqueloba and Neogloboquadrina pachyderma (s) between 688 and $645 \mathrm{~cm}$ in core RHS-KS65, and from 797 to $410 \mathrm{~cm}$ in core RHS-KS67 (Fig. 7) are representative of the last part of the LGM (ca. 20-18.5 cal. ka BP).

\subsection{Age model}

The age model of both cores is based upon the correlation of the oxygen isotope fluctuations of Globigerina bulloides with those in the reference core MD99-2346 (Melki et al., 2009). Because the $0-20$ cal. ka BP interval shows striking resemblances on all cores (Fig. 9a-d), we estimated that the synchronization of isotopic signals between these cores (Tab. 5) would give a more precise age model than the simple use of ${ }^{14} \mathrm{C}$ calibrated ages. Time boundaries of climatic events used here correspond to the synthesis between the stratigraphic timescale for the NGRIP ice core (Rasmussen et al., 2006) and the GICCO5 chronology (Andersen et al., 2007).

Oxygen isotopes values and fluctuations in cores RHS-KS65 and RHS-KS67 match remarkably well those in cores located in the western Gulf of Lions (i.e. MD99-2346), and in the Ligurian Sea (Bonneau et al., 2014; Jorry et al., 2011), showing that sea-surface hydrographical parameters were similar in these areas during the last 20 cal. ka BP (Fig. 9a-d). The events identified and dated in detail by Melki et al. (2009) are therefore easy to identify on cores RHS-KS65 and RHS-KS67. A maximum in the $\partial^{18} \mathrm{O}(\sim 4.3 \%$ ) is clearly observed in both cores and can be correlated to the last part of the Last Glacial Maximum (LGM) between 18.5-20 cal. ka BP (Tab. 5 and Fig. 9b) (Jorry et al., 2011; Melki et al., 2009; Sierro et al., 2009). HS 1 starts around 18.5 cal. ka BP and terminates at ca. 14.7 cal. ka BP (Jorry et al., 2011; Melki et al., 2009). During this event, the sharp increase of $\partial^{18} \mathrm{O}$ clearly identified on both cores is attributed to the freshening and to the slight cooling of the Mediterranean surface waters (Melki et al., 2009), in relation with the inflow of Northern Atlantic water during the episode of massive iceberg melting dated at ca. 16-15 cal. ka BP (Melki et al., 
2009; Sierro et al., 2005). The ensuing rapid decrease of $\partial^{18} \mathrm{O}$ is correlated to the warming of surface waters during the Bølling-Allerød Interstadial between 14.7 and 12.7 cal. ka BP (Melki et al., 2009). The Younger Dryas Stadial that interrupted the warming between ca. 12.8-11.7 cal. ka $\mathrm{BP}$ is well marked by a plateau of $\partial^{18} \mathrm{O}$ at $3.0 \%$. The onset of the Holocene is characterized by the lowest values of $\partial^{18} \mathrm{O}$ about $1.0 \%$, and is dated at $10 \mathrm{cal}$. ka BP (Melki et al., 2009). In both cores, the Holocene interval is condensed and represents less than $90 \mathrm{~cm}$ of sediment.

Radiocarbon dating carried out on G. bulloides planktonic foraminifera in cores RHS-KS65 and RHS-KS67 (Tab. 2) show some discrepancies, ranging between +800 to $-1,400 \mathrm{yr}$ with our age model, and one age reversal in core RHS-KS67. This shows that in such depositional environment, prone to reworking, it is more reliable to develop an age model based on the fluctuations of a continuous record, such as oxygen isotopes, rather than on few punctual radiocarbon dates. This is further evidenced by the good agreement of oxygen isotopes chronostratigraphy with the fluctuations of foraminifer assemblages described in paragraph 4.2 (Fig. 7).

\subsection{Linear sedimentation rates, turbidite frequency, grain-size and thickness}

\subsubsection{Linear sedimentation rates}

The post-glacial hemipelagic lithofacies at both sites show remarkably synchronous fluctuations of the linear sedimentation rate (LSR). The LSR gradually decreases, but is always much higher on the canyon terrace (RHS-KS65), where it ranges between 40 and $130 \mathrm{~cm} \cdot \mathrm{ky}^{-1}$, than

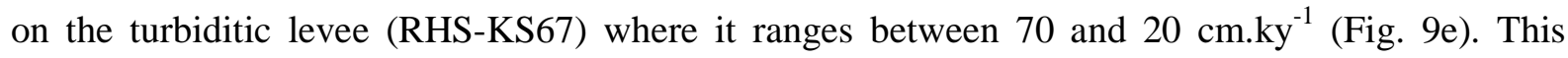
difference is particularly pronounced during HS 1. On the other hand, during the LGM, the LSR on the levee is much higher and reaches $280 \mathrm{~cm} \cdot \mathrm{ky}^{-1}$ while it reaches only $120 \mathrm{~cm} \cdot \mathrm{ky}^{-1}$ on the terrace (Figs. 9e and 10c). However, for this period, the age model is not well constrained on the canyon terrace and this result must be interpreted with caution. During the Holocene, LSR is similar at both sites, around 2-3 cm.ky ${ }^{-1}$. 


\subsubsection{Frequency of turbidites}

Turbidites were identified on the basis of the occurrence of coarse layers (i.e. silt or coarser), and counted in two groups: laminae (thickness $<1 \mathrm{~mm}$ ) and beds (thickness $>1 \mathrm{~mm}$ ). Turbidites are only found in the levee (core RHS-KS67), while on the terrace, inside the canyon, (core RHSKS65) only one discontinuous silt lamina at ca. 12 cal. ka BP (during the Younger Dryas) can be interpreted as a turbidite (Fig. 5). On the levee, the frequency of turbidites varies between 1 and 42 turbidites/250 yrs (Figs. 9f and 10d). The turbiditic lithofacies can be divided into four periods: (1) between 20 and 19 cal. ka BP, the frequency is around 15-20 turbidites/250 yrs with a maximum at 40 turbidites/250 yrs, around 19 cal. ka BP; (2) between 19 and $18.5 \mathrm{cal}$. ka BP, the frequency decreases gradually to 12 turbidites/250 yrs, (3) between 18.25 - 16.5 the frequency fluctuates between 1 and 4 turbidites/250 yrs; (4) between 16 cal. ka BP and the Present, only one turbidite was deposited at the end of the Bølling-Allerød. The frequency of turbiditic beds and laminae shows slightly different patterns. The frequency of "bed" turbidites remains constant at ca. 20 turbidites/250 yrs until ca. $19 \mathrm{cal}$. ka BP when it decreases abruptly, reaching 2 turbidites/250 yrs at $18 \mathrm{cal}$. ka BP. The frequency of "laminae" turbidites increases to 30 turbidites/250 yrs at $19 \mathrm{cal}$. ka BP and decreases at zero at 16.5 cal. ka BP. Between 20 and 19 cal. ka BP, "bed" turbidites are dominant (60-94\% of the turbidites), whereas between 19-16.5 cal. ka BP, "laminae" turbidites are dominant $(60-100 \%$ of the turbidites).

\subsubsection{Thickness of turbidites and grain size patterns}

The thickness of "bed" turbidites ranges from 0.2 to $8 \mathrm{~cm}$, and the median grain size, at the base of the beds, ranges from 20 to $60 \mu \mathrm{m}$ (Figs. 10a and 10b). Sand is very rare and represents only 1$4 \%$ in the coarsest part of the beds (Figs $6 \mathrm{a}$ and $6 \mathrm{~b}$ ). Fluctuations in grain-size and thickness show a rough sub-millennial time-scale periodicity of ca. 200 years between 19.5-18.5 cal. ka BP (Figs. 10a and $10 \mathrm{~b}$ ). This corresponds to depositional intervals of ca. $30 \mathrm{~cm}$. In addition to this periodicity, both parameters show significant trends. The overall thickness of turbidites gradually decreases 
from "bed" turbidites to "laminae" turbidites. In addition, the grain size decreases gradually between 20-19.5 cal. ka BP and then increases gradually until 17 cal. ka BP (Fig. 10b). The particularly thick turbiditic beds at the base of core RHS-KS67 correspond to lithofacies 4d that is characterized by reverse grading, and interpreted as hyperpycnites, (see discussion). It is noticeable that between 19-20 cal. ka BP, the fluctuations in the basal grain size are well, inversely, correlated to the frequency of bed turbidites with a marked change in trends around ca. 19.25-19.5 cal. ka BP (Fig. 10d). It is noteworthy that the change in the trends is also coeval to the transition from lithofacies $4 \mathrm{~d}$ (hyperpycnites) to lithofacies $4 \mathrm{c}$ (slope failure turbidites) (Fig. 5). This shows that hyperpycnal turbidity currents were more frequent and coarser than slope failure turbidites.

\section{Discussion}

\subsection{Assessing the preservation of the pelagic signal in a turbiditic environment.}

Establishing a chronostratigraphic framework in turbiditic deposits remains a challenge because the datable particles deposited by turbidity currents (organic carbon, biogenic carbonates) have been eroded and reworked (either onshore or offshore). Nevertheless, in turbiditic environments, the accumulation of sediment occurs dominantly during short-lived events (a few hours to a few days) and the quiescence between two turbidity currents can be long enough to accumulate and preserve some hemipelagic material (Te term, see Stow and Piper (1984) for a thorough review). It is therefore reasonable to target these intervals in order to build a chronostratigraphic framework based on the microfossil record. This approach has been successfully used in several turbidite systems for the Late Pleistocene, e.g. in the Mediterranean Sea

(Bonneau et al., 2014; Ducassou, 2006; Jorry et al., 2011), North Atlantic (Henrich et al., 2010; Pierau et al., 2010; Toucanne et al., 2012), West Africa (Henrich et al., 2010; Pierau et al., 2010), Arabian sea (Bourget et al., 2010), and in the Pacific Ocean (Nakajima and Itaki, 2007; Pouderoux et al., 2012). 
The same approach was followed for dating the Rhone turbidites. Since a pelagic interval was nearly impossible to differentiate from the muddy top of a turbidite, the sampling was done in the muddy interval of lithofacies $4 \mathrm{~b}$ and $4 \mathrm{~d}$ and in lithofacies $4 \mathrm{a}$ by avoiding as much as possible the silt laminae. The planktonic and benthic foraminiferal abundances and assemblages were determined at a high resolution in turbiditic sequences in order to evaluate the degree of dilution of the biogeneous material by the terrigenous material, as well as their degree of reworking.

Unsurprisingly, it is in the coarser layers of the turbidites that evidence of reworking and transport is found (Zaragosi et al., 2006). Foraminifera are less abundant (ca. 0-10\%) than in the pelagic interval (60-90\%), but they can sometimes represent up to $40 \%$ of the sand fraction (Fig. 8 , lithofacies 4d) showing that a significant amount of biogenous material can be transported in the turbidity currents. Within turbiditic lithofacies, benthic foraminifera are more abundant than in the pelagic lithofacies and among the benthic foraminifera, the shelf species Siphonaperta aspera is the most abundant. This is additional evidence for the shelf-related source of the reworked material, but probably also the consequence of the selective sorting by the hydro-sedimentary processes because S. aspera is a large flat-shaped foraminiferal species, prone to move with bottom currents and subsequently to be deposited with turbiditic sands. The amount of fragmented tests (20-40\%) is more important than in the pelagic and hemipelagic facies (10-20\%) giving further evidence of reworking and transport. Cassidulina laevigata var. carinata is a species with high abundance at the uppermost slope and outermost shelf. Hence, its high presence in the terrigenous sediments is a good indicator for reworking and resuspension by downslope/turbidity currents. (Duros et al., 2012; Duros et al., 2014). The reworked sediments can contain up to $20 \%$ of G. bulloides. Hence, sampling of foraminifers from these intervals for isotope analysis has to be avoided.

The muddy layers on top of turbiditic lithofacies show very similar characteristics to hemipelagic lithofacies regarding the abundance and assemblages of foraminifera, the amount of test fragments and the relative abundance of planktonic foraminifera. Shelf species (S. aspera) are 
slightly more abundant than in the hemipelagic lithofacies. However, it is probably mixed with the muddy term of the turbidites by the bioturbation, so that this muddy interval corresponds to the $T 8$ term (Stow and Piper, 1984).

Our results show that the pelagic material found in the muddy intervals of the turbidites is suitable for chronostratigraphic and paleoceanographic purposes. A particular attention must be paid to avoid the underlying coarse (silty) intervals because they can contain a significant amount of pelagic foraminifera, among which G. bulloides that is commonly used for oxygen isotopes analysis. The amount of shelf benthic foraminifera seems useless as indicator of reworking by turbidity currents because the reworking of shelf benthic foraminifera can also be attributed to other processes such as sediment particle transport by nepheloid plumes (Duros et al., 2012) and can thus occur in pelagic environments. On the other side, shell fragmentation, and, indeed, the amount of lithic grains, seems a reliable proxy for reworking by turbidity currents. We conclude that muddy turbiditic layers with more than $15 \%$ of test fragments may contain too much reworked material and may not be suitable for chronostratigraphic purpose. This assumption is valid only if fragmentation of tests is not related to the dissolution of carbonates.

\subsection{Spatial and morphological controls on sedimentary processes}

The canyon terrace and the turbiditic valley show drastically different sedimentary lithofacies and sedimentation rates. Having a good chronostratigraphic framework at both sites allows disentangling temporal fluctuation from those related to the site morphological features. The lithofacies point out that during the LGM, turbidites were deposited only in the turbiditic valley while at the same time the canyon terrace has recorded hemipelagic-type silty-clay lithofacies (Fig. 5). This demonstrates that during this period, the main depocenter was located at the base of slope and not close to the canyon head (i.e. to the Rhone River mouth), and that the transfer of sediment onto the margin was dominated by seabed transport (turbidity currents) along the Petit-Rhone canyon. The absence of turbidites on the terrace (RHS-KS65, situated $382 \mathrm{~m}$ above the canyon) 
suggests that the turbidity currents remained confined within the canyon (Fig. 4a), while overflow have occurred along the turbiditic valley where the thalweg is shallower $(138 \mathrm{~m})$ (Fig. 4b). Nevertheless, it cannot be discarded that the faint laminae in lithofacies 3 result from the overflow of the highest parts of turbiditic plumes, since turbidites have been reported at very high elevations with respect to the turbiditic channel in other turbiditic systems such as the Var Sedimentary Ridge (Jorry et al., 2011; Migeon et al., 2012) or on terraces in the Congo Canyon (Babonneau et al., 2004) (400 m and $800 \mathrm{~m}$, respectively). It is noteworthy that the shallow, most recent, deposits on the Petit-Rhone Canyon terraces (Fig. 4) show a horizontal and parallel seismic stratigraphic pattern, indicative of deposition under hemipelagic processes. Deeper buried deposits clearly show a wedged pattern, thicker towards the canyon (Fig. 4), that is indicative of deposition by sediment spillover from the canyon, as this is commonly described on turbiditic levees in several mud-rich turbidite systems (e.g. Droz and Bellaiche 1985 on the Rhone; Flood et al. 1991 on the Amazon; Babonneau et al. 2002 on the Zaire/Congo). This shows that energetic sediment spillover from the canyon has occurred on the terrace in the past, possibly during the Last Glacial period, but that during the early Deglacial, hemipelagic settling was dominant and very important when regarding

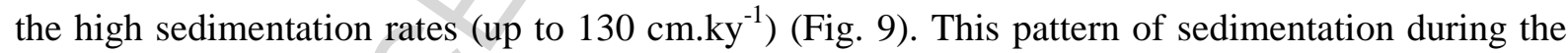
early Deglacial can be explained by the overflow and settling of the low-energy suspension cloud of the upper part of turbidity currents, as still some turbidites have been deposited in the turbiditic valley at the same period of time. On the other hand, this can be also explained by the settling of the Rhone River plumes, because, nowadays, during major floods such as during the December 2003 Rhone flood, the River plume can propagate tens of kilometres offshore, as seen on satellite images (Nasa Visible Earth, 2003), and this is in the range of the distance between the terrace and the Rhone River mouth during the Deglacial. After the LGM, despite the occurrence of some turbidites in the valley, the deposits in the two cores do not show evidence of energetic hydro-sedimentary processes. Having higher hemipelagic sedimentation rates on the canyon terrace (proximal location) 
than on the valley (distal location) is further evidence that sedimentary processes were driven by the settling of the surface hypopycnal river plume whose sediment concentration and settling gradually decrease seawards. Similar gradients of LSR related to settling of a river plume have been described in the Bay of Biscay during the Deglacial discharge of the Fleuve Manche palaeoriver (Toucanne et al., 2010) and show that during this period of time, the transfer of sediment on the slope and base of slope was dominated by surface hypopycnal transport.

\subsection{Hyperpycnites within the Rhone Turbidite System ?}

Hyperpycnites record the waxing and waning flow of a river flood (Mulder and Syvitski, 1995; Mulder et al., 2003). These deposits differ from classic Bouma turbidites by reverse to normal graded beds and sedimentary structures illustrating waxing to waning flow. In total, we identified 11 turbiditic beds of possible hyperpycnal origin within the lowermost $170 \mathrm{~cm}$ of core RHS-KS67, which corresponds to the period of time from 20 to 19.5 cal. ka BP. These beds show a very distinct coarsening- then fining-upward pattern (Fig. 6b). This suggests the presence in the turbiditic valley of high-density gravity flows triggered by hyperpycnal currents within the Rhone River at a time of direct fluvial-canyon connection. Indeed, sediment concentrations about $40 \mathrm{~kg} \mathrm{~m}^{-3}$, able to induce these processes, are produced preferentially within small-sized rivers (Mulder and Syvitski, 1995), but it has been proposed that concentration of sediment by convection processes within hypopycnal plumes at sediment concentrations as low as $1 \mathrm{~kg} \cdot \mathrm{m}^{3}$ can generate hyperpycnal plumes (Parsons et al., 2001). Kettner and Syvitski (2009) modelled sediment fluxes of 3 Mediterranean rivers (Rhone, Po and Tet) and showed that only the Tet River had presently the ability to generate hyperpycnal plumes. However, these authors predicted, for the Last Glacial Maximum, sediment discharges from the Rhone in the order of 10-12 times present-day values, due to glacier ablation. They also calculated sediment concentrations of about $30 \mathrm{~kg} . \mathrm{m}^{-3}$ (with a recurrence interval of 200 years), a value in the same order as that required for hyperpycnal processes. It can be pointed that, after a maximum extension of ice sheets in the Alps during the LGM, a phase of retreat of the Rhone 
Glacier started at ca. 20 cal. ka BP, with a massive recession around 18 cal. ka BP (Ivy-Ochs et al., 2008) (Fig. 11b). Our findings are in very good agreement with the expected high sediment flux resulting from this retreat, if we consider that the dampening effect of periglacial lakes was minor (Hinderer, 2001).

Moreover, before ca 19.5 cal. ka BP, sea level was relatively stable or rose slowly at a rate of ca. $1 \mathrm{~m} \mathrm{ky}^{-1}$ (Clark et al., 2004; Clark et al., 2012; Hanebuth et al., 2000; Hanebuth et al., 2009). That stillstand condition around $120 \mathrm{~m}$ below present sea level maintained the connection between the Rhone River mouth and the Petit Rhone Canyon head, favouring a direct transfer of sediment from the river into the canyon.

\subsection{Sea-level control on turbiditic activity along the Rhone Turbidite System}

Our data show major changes in the sedimentation processes in the canyon and in the turbiditic valley, that we can accurately date and correlate to sea-level fluctuations (Figs. 11 and 12):

- Between 20 and ca. 19.5-19 cal. ka BP, lithofacies 4c and 4d outline turbiditic processes controlled by a probable direct connection between the Rhone River mouth and the canyon and including hyperpycnites.

- At ca. 19.5-19 and 18.5 cal. ka BP, lithofacies $4 \mathrm{a}$ and $4 \mathrm{~b}$ outline turbiditic processes controlled by small-scale sediment failures at the canyon head.

- After 18.5-18 cal. ka BP, the turbidites become scarce and the LSR drastically decreases in the valley.

- During the Holocene, lithofacies 1 is dominantly pelagic and shows no evidence of major terrigenous input.

The cessation of hyperpycnal processes between 19.5 and 19 cal. ka BP, is concomitant to the 19-ka MWP that has been described by several authors (Clark et al., 2004; Clark et al., 2012; Hanebuth et al., 2000; Hanebuth et al., 2009; Yokoyama et al., 2001). The onset of this event is 
dated between 19.4 and 19.0 cal. ka BP, depending on the different authors, and lasted about 500$800 \mathrm{yrs}$, with a rise in the order of $10 \mathrm{~m}$. We postulate that this rise generated a disconnection of the Rhone River with the canyon head and a change in the triggering mechanism of turbidity currents, shifting from hyperpycnal currents initiated at the river mouth to ignitive currents generated by slope failures at the canyon head.

The abrupt fall of LSR and frequency of turbidites at 18.5-18 cal. ka BP (Fig. 11f), corresponds to the end of the 19-ka MWP, when the sea-level was comprised between 110 and 100 m (Clark et al., 2012; Hanebuth et al., 2009; Lambeck and Bard, 2000). According to these authors, global sea-level was comprised between 110 and $100 \mathrm{~m}$ at this time.. At this time, the distance between the canyon head and the Rhone outlet was in the order of $50 \mathrm{~km}$, and most of the suspended sediment supplied by the river was probably advected toward the west by the thermohaline and wind-driven circulation, as presently observed in the modern "highstand" situation (Millot 1991). Therefore, mass failures became rare, and the entire Rhone Turbidite System was starved of sediment as demonstrated by studies on the Deep Sea-Fan (Bonnel et al., 2005; Dennielou et al., 2006), which yield a similar age (ca. 18 cal. ka BP) for cessation of functioning of the turbiditic channel. Episodic turbiditic activity persisted however along the entire continental margin, during the Deglacial and the entire Holocene, in relation with other processes such as dense water cascades, earthquakes and/or localized mass wasting (Dennielou et al., 2009). Our finding contradicts the classification of the Rhone Turbidite System as a "transgressiondominant system" by Covault and Graham (2010). Indeed, our results as well as previous studies of Bonnel (2005) and Dennielou et al. (2006), demonstrate that the Rhone Turbidite System is a lowstand-dominant system in the terminology of these authors, i.e. a system where maximum deposition occurred during the sea-level lowstand. 


\section{Conclusions}

1- Our study shows that paleoceanographic fluctuations recorded by planktonic foraminifera can be satisfactory preserved in a dominantly turbiditic sedimentary environment, provided that samples are carefully sampled at the top of each depositional sequence (from non-reworked specimens within hemipelagic beds, i-e $T d$ and $T e$ terms of the Bouma classification). This methodology allows to carry out paleoceanographic studies at very high resolution, due to high sedimentation rates that prevail in such settings, at least during periods of connection between fluvial systems and canyon heads.

2- For the first time in the Rhone Turbidite System, we show evidences of turbidites generated by hyperpycnal currents. This process was favoured by (a) the direct connection of the Rhone River with the Petit-Rhone canyon head during the LGM and early Deglacial, and (b) high sediment load related to the onset of massive recession of the Rhone Glaciers, which may have generated high-density gravity flows at the river mouth, with concentration sufficient to plunge into the canyon head.

3- The Rhone Turbidite System is a lowstand-dominant system in the sense of Covault and Graham (2010). This is outlined by the frequent deposition of turbidites during the LGM (up to 40 per kyr) and by the abrupt drop of turbiditic activity after the 19-ka MWP. The 19-ka MWP is not only marked by a decrease of turbiditic activity, but also by a change of turbiditic lithofacies due to different processes before and after fluvial disconnection: (a) hyperpycnal currents initiated at the river mouth before 19-ka MWP, (b) ignitive flows generated by slope failures at the canyon head after 19-ka MWP.

4- Sea-level is therefore a major controlling factor of the functioning of the Rhone Turbidite System, not only in terms of frequency of gravity events, but by controlling the processes (hyperpycnal vs "Bouma-type") at the origin of the turbiditic record. 


\section{Acknowledgements}

The Master and crew of "R/V Suroit" and technical staff of Genavir are thanked for their assistance during the "RHOSOS" cruise. IFREMER technical staff is thanked for help in processing of sedimentological data (G. Floch, M. Rovere, A. Roubi), multibeam data (A. Normand) and chirp data (E. Thereau). N. Andersen (Leibniz Laboratory for Radiometric Dating and Stable Isotope Research) and R. Schneider (Institut für Geowissenschaften, University of Kiel) are thanked for their help for stable isotopes analysis. C. Angué Minto'o is thanked for picking foraminifera used for oxygen isotopes analysis. E. Petit helped for picking foraminifera for radiocarbon dating and isotope analysis, and A. Boissier was a great support for the use of Grapher software. S. Lombo Tombo received a mobility fellowship from LabexMER (http://www.labexmer.eu) Axis 4 "Sediment transfer from the coast to the abyss", supported by Agence Nationale de la Recherche (ANR-10-LABX-19-01). S. Lombo Tombo acknowledges the Gabonese Agence Nationale des Bourses (ANBG) and IFREMER for awarding a doctoral scholarship. This work is a contribution to IFREMER project "Systèmes et Evolutions Sédimentaires" and to Université Perpignan Via Domitia and CNRS "Centre de Formation et de Recherche sur les Environnements Méditerranéens" (UMR 5110) project “Archives Sédimentaires”. We thank the ARTEMIS program (INSU-CNRS) for providing ${ }^{14} \mathrm{C}$ dates at Mass Spectrometer Accelerator Laboratory (Saclay, Gif-sur-Yvette). Walter R. Roest kindly corrected the English. We thank Heinrich Bahlburg and an anonymous reviewer for their constructive reviews. 


\section{Appendix table captions}

Table A1: Foraminiferal assemblages based on counting on the size fraction $>150 \mu \mathrm{m}$ in core RHSKS65.

Table A2: Foraminiferal assemblages based on counting on the size fraction $>150 \mu \mathrm{m}$ in the muddy intervals from core RHS-KS67.

\section{Appendix figure captions}

Figure A1: Relative abundance of planktonic foraminiferal species in the lithofacies of core RHSKS67. a) photography, b) radiography, c) lithofacies.

Figure A2: Relative abundance of autochtonous benthic foraminiferal species in the lithofacies of core RHS-KS67. a) photography, b) radiography, c) lithofacies.

Figure A3: Relative abundance of allochtonous benthic foraminiferal species in the lithofacies of core RHS-KS67. a) photography, b) radiography, c) lithofacies. 


\section{References}

Allen, P. A., 2008. Time scales of tectonic landscapes and their sediment routing systems. Geological Society, London, Special Publications 296, 7-28.

Aloïsi, J.-C., 1986. Sur un modèle de sédimentation deltaïque. Contribution à la connaissance des marges passives, University of Perpignan.

Andersen, K. K., Bigler, M., Buchardt, S. L., Clausen, H. B., Dahl-Jensen, D., Davies, S. M., Fischer, H., Goto-Azuma, K., Hansson, M. E., Heinemeier, J., Johnsen, S. J., Larsen, L. B., Muscheler, R., Olsen, G. J., Rasmussen, S. O., Röthlisberger, R., Ruth, U., Seierstad, I. K., Siggaard-Andersen, M.L., Steffensen, J. P., Svensson, A. M., and Vinther, B. M., 2007. Greenland Ice Core Chronology 2005 (GICC05) and 20 year means of oxygen isotope data from ice core NGRIP. PANGAEA - Data Publisher for Earth \& Environmental Science.

Antobreh, A. A. and Krastel, S., 2006. Morphology, seismic characteristics and development of Cap Timiris Canyon, offshore Mauritania: A newly discovered canyon preserved-off a major arid climatic region. Marine and Petroleum Geology 23, 37-59.

Babonneau, N., Savoye, B., Cremer, M., and Bez, M., 2004. Multiple terraces within the deep incised Zaire Valley (ZaïAngo Project): are they confined levees? In: Lomas, S. A. and Joseph, P. Eds.), Confined Turbidite Systems. Geological Society. Special Publications, London.

Babonneau, N., Savoye, B., Cremer, M., and Klein, B., 2002. Morphology and architecture of the present canyon and channel system of the Zaire deep-sea fan. Marine and Petroleum Geology 19, 445-467.

Bache, F., Popescu, S.-M., Rabineau, M., Gorini, C., Suc, J.-P., Clauzon, G., Olivet, J.-L., Rubino, J.-L., Melinte-Dobrinescu, M. C., Estrada, F., Londeix, L., Armijo, R., Meyer, B., Jolivet, L., Jouannic, G., Leroux, E., Aslanian, D., Dos Reis, A. T., Mocochain, L., Dumurdzanov, N., Zagorchev, I., Lesic, V., Tomic, D., Cagatay, M. N., Brun, J.-P., Sokoutis, D., Csato, I., Ucarkus, G., and Cakir, Z., 2012. A two-step process for the reflooding of the Mediterranean after the Messinian Salinity Crisis. Basin Research 24, 125-153.

Bassetti, M. A., Berne, S., Jouet, G., Taviani, M., Dennielou, B., Flores, J. A., Gaillot, A., Gelfort, R., Lafuerza, S., and Sultan, N., 2008. The 100-ka and rapid sea level changes recorded by prograding shelf sand bodies in the Gulf of Lions (western Mediterranean Sea). Geochemistry Geophysics Geosystems 9.

Bassetti, M. A., Jouet, G., Dufois, F., Berné, S., Rabineau, M., and Taviani, M., 2006. Sand bodies at the shelf edge in the Gulf of Lions (Western Mediterranean): Deglacial history and modern processes. Marine Geology 234, 93-109.

Baztan, J., Berné, S., Olivet, J. L., Rabineau, M., Aslanian, D., Gaudin, M., Réhault, J. P., and Canals, M., 2005. Axial incision: The key to understand submarine canyon evolution (in the western Gulf of Lion). Marine and Petroleum Geology 22, 805-826.

Beaudouin, C., Dennielou, B., Melki, T., Guichard, F., Kallel, N., Berné, S., and Huchon, A., 2004. The Late-Quaternary climatic signal recorded in a deep-sea turbiditic levee (Rhône Neofan, Gulf of Lions, NW Mediterranean): palynological constraints. Sedimentary Geology 172, 85-97.

Berné, S., Jouet, G., Bassetti, M. A., Dennielou, B., and Taviani, M., 2007. Late Glacial to Preboreal sealevel rise recorded by the Rhone deltaic system (NW Mediterranean). Marine Geology 245, 65-88.

Berne, S., Lericolais, G., Marsset, T., Bourillet, J. F., and De Batist, M., 1998. Erosional offshore sand ridges and lowstand shorefaces: Examples from tide- and wave-dominated environments of France. Journal of Sedimentary Research 68, 540-555.

Blanc-Vernet, L., 1969. Contribution à l'étude des foraminifères de Méditerranée: relations entre la microfaune et le sédiment ; biocoenoses actuelles, thanatocoenoses pliocènes et quaternaires. Impr. Louis-Jean, Marseille.

Bonneau, L., Jorry, S. J., Toucanne, S., Jacinto, R. S., and Emmanuel, L., 2014. Millennial-Scale Response of a Western Mediterranean River to Late Quaternary Climate Changes: A View from the Deep Sea. The Journal of Geology 122, 687-703.

Bonnel, C., Dennielou, B., Droz, L., Mulder, T., and Berné, S., 2005. Architecture and depositional pattern of the Rhône Neofan and recent gravity activity in the Gulf of Lions (western Mediterranean). Marine and Petroleum Geology 22, 827-843. 
Bouma, A. H., 2001. Fine-grained submarine fans as possible recorders of long- and short-term climatic changes. Global and Planetary Change 28, 85-91.

Bourget, J., Zaragosi, S., Ellouz-Zimmermann, S., Ducassou, E., Prins, M. A., Garlan, T., Lanfumey, V., Schneider, J. L., Rouillard, P., and Giraudeau, J., 2010. Highstand vs. lowstand turbidite system growth in the Makran active margin: Imprints of high-frequency external controls on sediment delivery mechanisms to deep water systems. Marine Geology 274, 187-208.

Canals, M., Puig, P., de Madron, X. D., Heussner, S., Palanques, A., and Fabres, J., 2006. Flushing submarine canyons. Nature 444, 354-357.

Castelltort, S. and Van Den Driessche, J., 2003. How plausible are high-frequency sediment supply-driven cycles in the stratigraphic record? Sedimentary Geology 157, 3-13.

Cirac, P., Bourillet, J., Griboulard, R., Normand, A., and Thierry, 2001. Canyon of Capbreton: new morphostructural and morphosedimentary approaches. First results of the ITSAS cruise. Comptes Rendus de l'Academie des Sciences Series IIA Earth and Planetary Science 332, 447-455.

Clark, P. U., Dyke, A. S., Shakun, J. D., Carlson, A. E., Clark, J., Wohlfarth, B., Mitrovica, J. X., Hostetler, S. W., and McCabe, A. M., 2009. The Last Glacial Maximum. Science 325, 710-714.

Clark, P. U., McCabe, A. M., Mix, A. C., and Weaver, A. J., 2004. Rapid rise of sea level 19,000 years ago and its global implications. Science 304, 1141-1144.

Clark, P. U., Shakun, J. D., Baker, P. A., Bartlein, P. J., Brewer, S., Brook, E., Carlson, A. E., Cheng, H., Kaufman, D. S., Liu, Z., Marchitto, T. M., Mix, A. C., Morrill, C., Otto-Bliesner, B. L., Pahnke, K., Russell, J. M., Whitlock, C., Adkins, J. F., Blois, J. L., Clark, J., Colman, S. M., Curry, W. B., Flower, B. P., He, F., Johnson, T. C., Lynch-Stieglitz, J., Markgraf, V., McManus, J., Mitrovica, J. X., Moreno, P. I., and Williams, J. W., 2012. Global climate evolution during the last deglaciation. Proceedings of the National Academy of Sciences 109, E1134-E1142.

Clauzon, G., 1973. The eustatic hypothesis and the pre-Pliocene cutting of the Rhône valley. In: Ryan, W. B. F. and Hsü, K. J. Eds.), Initial Reports of the Deep Sea Drilling Project.

Covault, J. A. and Graham, S. A., 2010. Submarine fans at all sea-level stands: Tectono-morphologic and climatic controls on terrigenous sediment delivery to the deep sea. Geology 38, 939-942.

Curray, J. R., Emmel, F. J., and Moore, D. G., 2002. The Bengal Fan: morphology, geometry, stratigraphy, history and processes. Marine and Petroleum Geology 19, 1191-1223.

D.S, G., 1988. Submarine fans and related turbidite systems: (Frontiers in Sedimentary Geology.) A.H. Bouma, W.R. Normark and N.E. Barnes (Editors). Springer, New York, N.Y., 1985, ISBN 3-54096142-9, xiv + 351 pp., DM 220 (hardcover). Sedimentary Geology 54, 347-348.

Dennielou, B., Huchon, A., Beaudouin, C., and Berne, S., 2006. Vertical grain-size variability within a turbidite levee: Autocyclicity or allocyclicity? A case study from the Rhone neofan, Gulf of Lions, Western Mediterranean. Marine Geology 234, 191-213.

Dennielou, B., Jallet, L., Sultan, N., Jouet, G., Giresse, P., Voisset, M., and Berné, S., 2009. Post-glacial persistence of turbiditic activity within the Rhône deep-sea turbidite system (Gulf of Lions, Western Mediterranean): Linking the outer shelf and the basin sedimentary records. Marine Geology 257, 6586.

dos Reis, A. T., Gorini, C., and Mauffret, A., 2005. Implications of salt-sediment interactions on the architecture of the Gulf of Lions deep-water sedimentary systems-western Mediterranean Sea. Marine and Petroleum Geology 22, 713-746.

Droz, L., 1983. L'éventail sous-marin profond du Rhône (Golfe du Lion) : grands traits morphologiques et structure semi-profonde, Université Paris 6.

Droz, L., dos Reis, A. T., Rabineau, M., Berne, S., and Bellaiche, G., 2006. Quaternary turbidite systems on the northern margins of the Balearic Basin (Western Mediterranean): a synthesis. Geo-Marine Letters 26, 347-359.

Droz, L., and Bellaiche, G., 1985, Rhone Deep-Sea Fan - Morphostructure and growth-pattern: Aapg Bulletin-American Association of Petroleum Geologists, v. 69, p. 460-479.

Droz, L., l'ocean, G. d. é. d. 1. m. c. e. d., sous-marine, L. d. g., oceanologique, O., and Curie, U. P. e. M., 1991. Les Eventails sous-marins profonds: structure et evolution sedimentaire : a partir de l'étude comparative des troisedifices: l'eventail du Rhône, la ride du Var, le cone de 1 'Indus.

Ducassou, E., 2006. Évolution du système turbiditique profond du Nil au cours du Quaternaire récent. 
Duros, P., Fontanier, C., de Stigter, H. C., Cesbron, F., Metzger, E., and Jorissen, F. J., 2012. Live and dead benthic foraminiferal faunas from Whittard Canyon (NE Atlantic): Focus on taphonomic processes and paleo-environmental applications. Marine Micropaleontology 94-95, 25-44.

Duros, P., Jorissen, F. J., Cesbron, F., Zaragosi, S., Schmidt, S., Metzger, E., and Fontanier, C., 2014. Benthic foraminiferal thanatocoenoses from the Cap-Ferret Canyon area (NE Atlantic): A complex interplay between hydro-sedimentary and biological processes. Deep Sea Research Part II: Topical Studies in Oceanography 104, 145-163.

Fanget, A.-S., 2009. Morphologie du canyon et du système turbiditique du Petit-Rhône et faciès sédimentaires Glaciaires et Holocènes. Université de Brest, Brest.

Fanget, A.-S., Berné, S., Jouet, G., Bassetti, M.-A., Dennielou, B., Maillet, G. M., and Tondut, M., 2014. Impact of relative sea level and rapid climate changes on the architecture and lithofacies of the Holocene Rhone subaqueous delta (Western Mediterranean Sea). Sedimentary Geology 305, 35-53.

Fanget, A. S., Bassetti, M. A., Arnaud, M., Chiffoleau, J. F., Cossa, D., Goineau, A., Fontanier, C., Buscail, R., Jouet, G., Maillet, G. M., Negri, A., Dennielou, B., and Berné, S., 2013. Historical evolution and extreme climate events during the last 400\&\#xa0;years on the Rhone prodelta (NW Mediterranean). Marine Geology 346, 375-391.

Flood, R., Manley, P., Kowsmann, R., Appi, C., and Pirmez, C., 1991. Seismic Facies and Late Quaternary Growth of Amazon Submarine Fan. In: Weimer, P. and Link, M. Eds.), Seismic Facies and Sedimentary Processes of Submarine Fans and Turbidite Systems. Springer New York.

Gaudin, M., Berné, S., Jouanneau, J. M., Palanques, A., Puig, P., Mulder, T., Cirac, P., Rabineau, M., and Imbert, P., 2006a. Massive sand beds attributed to deposition by dense water cascades in the Bourcart canyon head, Gulf of Lions (northwestern Mediterranean Sea). Marine Geology 234, 111128.

Gaudin, M., Mulder, T., Cirac, P., Berné, S., and Imbert, P., 2006b. Past and present sedimentary activity in the Capbreton Canyon, southern Bay of Biscay. Geo-Marine Letters 26, 331-345.

Gensous, B., Williamson, D., and Tesson, M., 2009. Late-Quaternary Transgressive and Highstand Deposits of a Deltaic Shelf (Rhône Delta, France), Sequence Stratigraphy and Facies Associations. Blackwell Publishing Ltd.

Hanebuth, T., Stattegger, K., and Grootes, P. M., 2000. Rapid flooding of the Sunda Shelf: A late-glacial sea-level record. Science 288, 1033-1035.

Hanebuth, T. J. J., Stattegger, K., and Bojanowski, A., 2009. Termination of the Last Glacial Maximum sealevel lowstand: The Sunda-Shelf data revisited. Global and Planetary Change 66, 76-84.

Henrich, R., Cherubini, Y., and Meggers, H., 2010. Climate and sea level induced turbidite activity in a canyon system offshore the hyperarid Western Sahara (Mauritania): The Timiris Canyon. Marine Geology 275, 178-198.

Hinderer, M., 2001. Late Quaternary denudation of the Alps, valley and lake fillings and modern river loads. Geodinamica Acta 14, 231-263.

Hsü, K. J., M.B. Cita and Ryan, W. B. F., 1973. The origin of the Mediterranean evaporites. In: Ryan, W. B. F. and Hsü, K. J. Eds.), Initial Reports of the Deep Sea Drilling Project.

Ivy-Ochs, S., Kerschner, H., Reuther, A., Preusser, F., Heine, K., Maisch, M., Kubik, P. W., and Schluchter, C., 2008. Chronology of the last glacial cycle in the European Alps. Journal of Quaternary Science 23, 559-573.

Jegou, I., 2008. Etude de la transition chenal-levées/lobe dans les systèmes turbiditiques récents. Application à l'éventail turbiditique de l'Amazone et au Néofan du Petit-Rhône, Université de Brest.

Jorry, S. J., Jégou, I., Emmanuel, L., Silva Jacinto, R., and Savoye, B., 2011. Turbiditic levee deposition in response to climate changes: The Var Sedimentary Ridge (Ligurian Sea). Marine Geology 279, 148161.

Jouet, G., 2007. Enregistrements stratigraphiques des cycles climatiques et eustatiques du Quaternaire terminal - Modélisations de la marge continentale du Golfe du Lion, Université de Bretagne Occidentale, Brest.

Jouet, G., Berné, S., Rabineau, M., Bassetti, M. A., Bernier, P., Dennielou, B., Sierro, F. J., Flores, J. A., and Taviani, M., 2006. Shoreface migrations at the shelf edge and sea-level changes around the Last Glacial Maximum (Gulf of Lions, NW Mediterranean). Marine Geology 234, 21-42.

Kettner, A. J. and Syvitski, J. P. M., 2009. Fluvial responses to environmental perturbations in the Northern Mediterranean since the Last Glacial Maximum. Quaternary Science Reviews 28, 2386-2397. 
Kolla, V. and Coumes, F., 1987. Morphology, internal structure, seismic stratigraphy, and sedimentation of Indus Fan. Aapg Bulletin 71, 650-677.

L'homer, A., Bazile, F., Thommeret, J., and Thommeret, Y., 1981. Principales étapes de l'édification du delta du Rhône de 7000 BP à nos jours; variations du niveau marin. Oceanis 7, 389-408.

Lambeck, K. and Bard, E., 2000. Sea-level change along the French Mediterranean coast for the past 30000 years. Earth and Planetary Science Letters 175, 203-222.

Le Pichon, X., Pautot, G., Auzende, J.-M., and Olivet, J.-L., 1971. La méditerranée occidentale depuis l'oligocène, schéma d'évolution. Marine Geophysical Researches 13, 145-152.

Lebreiro, S. M., Voelker, A. H. L., Vizcaino, A., Abrantes, F. G., Alt-Epping, U., Jung, S., Thouveny, N., and Gracia, E., 2009. Sediment instability on the Portuguese continental margin under abrupt glacial climate changes (last $60 \mathrm{kyr}$ ). Quaternary Science Reviews 28, 3211-3223.

Lofi, J., Rabineau, M., Gorini, C., Berne, S., Clauzon, G., De Clarens, P., Tadeu Dos Reis, A., Mountain, G. S., Ryan, W. B. F., Steckler, M. S., and Fouchet, C., 2003. Plio-Quaternary prograding clinoform wedges of the western Gulf of Lion continental margin (NW Mediterranean) after the Messinian Salinity Crisis. Marine Geology 198, 289-317.

Melki, T., Kallel, N., Jorissen, F. J., Guichard, F., Dennielou, B., Berne, S., Labeyrie, L., and Fontugne, M., 2009. Abrupt climate change, sea surface salinity and paleoproductivity in the western Mediterranean Sea (Gulf of Lion) during the last 28 kyr. Palaeogeography Palaeoclimatology Palaeoecology 279, 96-113.

Migeon, S., Mulder, T., Savoye, B., and Sage, F., 2012. Hydrodynamic processes, velocity structure and stratification in natural turbidity currents: Results inferred from field data in the Var Turbidite System. Sediment. Geol. 245-246, 48-62.

Millot, C., 1991. Mesoscale and seasonal variabilities of the circulation in the western Mediterranean. Dynamics of Atmospheres and Oceans 15, 179-214.

Mulder, T. and Alexander, J., 2001. The physical character of subaqueous sedimentary density flows and their deposits. Sedimentology 48, 269-299.

Mulder, T. and Syvitski, J. P., 1995. Turbidity currents generated at river mouths during exceptional discharges to the world oceans. The Journal of Geology, 285-299.

Mulder, T., Syvitski, J. P. M., Migeon, S., Faugères, J.-C., and Savoye, B., 2003. Marine hyperpycnal flows: initiation, behavior and related deposits. A review. Marine and Petroleum Geology 20, 861-882.

Nakajima, T. and Itaki, T., 2007. Late Quaternary terrestrial climatic variability recorded in deep-sea turbidites along the Toyama Deep-Sea Channel, central Japan Sea. Palaeogeography, Palaeoclimatology, Palaeoecology 247, 162-179.

Nasa Visible Earth., 2003. Floods in the southern France http://visibleearth.nasa.gov/view.php?id=69536.

O'Connell, S., Normark, W. R., Ryan, W. B. F., and Kenyon, N. H., 1991. An entrenched thalweh channel on the Rhone fan: interpretation from a seabeam and SEAMARC I survey. SEPM 46, 259-270.

Palanques, A., Durrieu de Madron, X., Puig, P., Fabres, J., Guillén, J., Calafat, A., Canals, M., Heussner, S., and Bonnin, J., 2006. Suspended sediment fluxes and transport processes in the Gulf of Lions submarine canyons. The role of storms and dense water cascading. Marine Geology 234, 43-61.

Parsons, J. D., Bush, J. W., and Syvitski, J. P., 2001. Hyperpycnal plume formation from riverine outflows with small sediment concentrations. Sedimentology 48, 465-478.

Pierau, R., Hanebuth, T. J. J., Krastel, S., and Henrich, R., 2010. Late Quaternary climatic events and sealevel changes recorded by turbidite activity, Dakar Canyon, NW Africa. Quaternary Research 73, 385-392.

Pirmez, C. and Flood, R., 1995. Morphology and structure of Amazon ChannelProceedings of the Ocean Drilling Program. Initial Reports. Ocean Drilling Program.

Posamentier, H. and Vail, P. R., 1988. Eustatic controls on clastic deposition II-sequence and systems tract models. In: Wilgus, C.K., Hastings, B.S., Kendall, C.G.St.C., Posamentier, H.W., Ross, C.A., Van Wagoner, J.C. (Eds.), Sea Level Changes-An Integrated Approach. SEPM Special Publication 42, $125-154$.

Pouderoux, H., Proust, J.-N., Lamarche, G., Orpin, A., and Neil, H., 2012. Postglacial (after 18 ka) deep-sea sedimentation along the Hikurangi subduction margin (New Zealand): Characterisation, timing and origin of turbidites. Marine Geology 295-298, 51-76. 
Rabineau, M., Berne, S., Olivet, J. L., Aslanian, D., Guillocheau, F., and Joseph, P., 2006. Paleo sea levels reconsidered from direct observation of paleoshoreline position during Glacial Maxima (for the last 500,000 yr). Earth and Planetary Science Letters 252, 119-137.

Reimer, P. J., Bard, E., Bayliss, A., Beck, J. W., Blackwell, P. G., Bronk Ramsey, C., Buck, C. E., Cheng, H., Edwards, R. L., Friedrich, M., Grootes, P. M., Guilderson, T. P., Haflidason, H., Hajdas, I., Hatté, C., Heaton, T. J., Hoffmann, D. L., Hogg, A. G., Hughen, K. A., Kaiser, K. F., Kromer, B., Manning, S. W., Niu, M., Reimer, R. W., Richards, D. A., Scott, E. M., Southon, J. R., Staff, R. A., Turney, C. S. M., and van der Plicht, J., 2013. IntCal13 and Marine13 Radiocarbon Age Calibration Curves 0-50,000 Years cal BP.

Sierro, F. J., Andersen, N., Bassetti, M. A., Berné, S., Canals, M., Curtis, J. H., Dennielou, B., Flores, J. A., Frigola, J., Gonzalez-Mora, B., Grimalt, J. O., Hodell, D. A., Jouet, G., Pérez-Folgado, M., and Schneider, R., 2009. Phase relationship between sea level and abrupt climate change. Quaternary Science Reviews 28, 2867-2881.

Sierro, F. J., Hodell, D. A., Curtis, J. H., Flores, J. A., Reguera, I., Colmenero-Hidalgo, E., Barcena, M. A., Grimalt, J. O., Cacho, I., Frigola, J., and Canals, M., 2005. Impact of iceberg melting on Mediterranean thermohaline circulation during Heinrich events. Paleoceanography 20.

Stow, D. A. V. and Piper, D. J. W., 1984. Deep-water fine-grained sediments: facies models. Geological Society, London, Special Publications 15, 611-646.

Tesson, M., Gensous, B., Allen, G. P., and Ravenne, C., 1990. Late Quaternary deltaic lowstand wedges on the Rhône continental shelf, France. Marine Geology 91, 325-332.

Torres, J., Droz, L., Savoye, B., Terentieva, E., Cochonat, P., Kenyon, N. H., and Canals, M., 1997. Deepsea avulsion and morphosedimentary evolution of the Rhône Fan Valley and Neofan during the Late Quaternary (north-western Mediterranean Sea). Sedimentology 44, 457-477.

Toucanne, S., Zaragosi, S., Bourillet, J.-F., Dennielou, B., Jorry, S. J., Jouet, G., and Cremer, M., 2012. External controls on turbidite sedimentation on the glacially-influenced Armorican margin (Bay of Biscay, western European margin). Marine Geology 303-306, 137-153.

Toucanne, S., Zaragosi, S., Bourillet, J. F., Marieu, V., Cremer, M., Kageyama, M., Van Vliet-Lanoe, B., Eynaud, F., Turon, J. L., and Gibbard, P. L., 2010. The first estimation of Fleuve Manche palaeoriver discharge during the last deglaciation: Evidence for Fennoscandian ice sheet meltwater flow in the English Channel ca 20-18 ka ago. Earth Planet. Sci. Lett. 290, 459-473.

Toucanne, S., Zaragosi, S., Bourillet, J. F., Naughton, F., Cremer, M., Eynaud, F., and Dennielou, B., 2008. Activity of the turbidite levees of the Celtic-Armorican margin (Bay of Biscay) during the last 30,000 years: Imprints of the last European deglaciation and Heinrich events. Marine Geology 247, 84-103.

Ulses, C., Estournel, C., Durrieu de Madron, X., and Palanques, A., 2008. Suspended sediment transport in the Gulf of Lions (NW Mediterranean): Impact of extreme storms and floods. Continental Shelf Research 28, 2048-2070.

Vella, C., Fleury, T.-J., Raccasi, G., Provansal, M., Sabatier, F., and Bourcier, M., 2005. Evolution of the Rhône delta plain in the Holocene. Marine Geology 222-223, 235-265.

Yokoyama, Y., Lambeck, K., De Deckker, P., Johnston, P., and Fifield, I. K., 2001. Timing of the Last Glacial Maximum from observed sea-level minima (vol 406, pg 713, 2000). Nature 412, 99-U19.

Zaragosi, S., Bourillet, J.-F., Eynaud, F., Toucanne, S., Denhard, B., Van Toer, A., and Lanfumey, V., 2006. The impact of the last European deglaciation on the deep-sea turbidite systems of the CelticArmorican margin (Bay of Biscay). Geo-Marine Letters 26, 317-329. 


\section{Table captions}

Table 1: List of studied cores (RHS-KS65 and RHS-KS67) and of core MD99-2346 (Melki et al., 2009). PLSR: Pyreneo-Languedocian Sedimentary Ridge.

Table 2: List of Radiocarbon analyses on planktonic foraminifera from sediment cores RHS-KS65 and RHS-KS67.

Table 3: Updated calibration of radiocarbon analyses on planktonic foraminifera from sediment core MD99-2346 after Melki et al (2009). Calibration made with Marine13 calibration curve (Reimer et al., 2013).

Table 4: Summary of lithofacies characteristics and comparison with other classifications. LSR: Linear Sedimentation Rate.

Table 5: Chronological tie points used for the age models of cores RHS-KS65 and RHS-KS67. Ages of tie points are based on the correlation of oxygen isotopes of Globigerina bulloides with those from core MD99-2346 (Melki et al., 2009). Calendar ages from core MD99-2346 are based on radiocarbon dating (Melki et al. 2009) calibrated with the Marine13 calibration curve (Reimer et al., 2013) (cf. Tab. 3).

Table 6: Foraminiferal assemblages in lithofacies 2, 3, 4b and 4d. Assemblages were determined on the fraction $>125 \mu \mathrm{m})$. Neogloboquadrina pachyderma dextral (N. pachyderma d); Chilostomella ovoidea (C. ovoidea); Gyroidina altiformis (G. altiformis); Melonis barleeanus (M. barleeanus); Cassidulina laevigata var. carinata (C. carinata); Bolivina spathulata (B. spathulata); Cibicides lobatulus (C. lobatulus); Siphonaperta aspera (S. aspera). 


\section{Figure captions}

Figure 1: Map of the Gulf of Lions (Dennielou et al., 2009) with position of the study area and the cores used in this study (Figs. 2 and 3). CC: Cap de Creus Canyon, LD: LacazeDuthiers Canyon; LF: La Fonera Canyon; P: Pruvot Canyon; Bo: Bourcart Canyon; He: Hérault Canyon; Se: Sète Canyon; Ma: Marti Canyon; PR: Petit-Rhone Canyon; GR: GrandRhone Canyon; Ms: Marseille Canyon; Pl : Planier Canyon; Ca: Cassidaigne Canyon, PLSR: Pyreneo-Languedocian Sedimentary Ridge. RTS: Rhone Turbidite System. Light grey on the shelf indicates location of shoreface sands after Aloïsi (1986) and modified by Berné et al. (2007). Medium grey with dashed rim indicates the location of the Rhone Turbidite System and of the Pyreneo-Languedocian Sedimentary Ridge. Yellow line indicates the Rhone River, the Petit-Rhone Canyon and the turbiditic channel. Black circles indicate sediment cores.

Figure 2: Detailed bathymetric map of the Petit-Rhone canyon head and outer Shelf, using Simrad EM300 swath-bathymetry system (Rhosos cruise).

Figure 3: Close-up view on the Petit-Rhone canyon, turbiditic valley and thalweg. Location of cores used in this study. (a) and (b) represent the location of chirp profiles shown in Fig 4.

Figure 4: Chirp profiles across the Rhone Turbidite System at the position of studied cores. a) Petit-Rhone canyon head with close-up view at the position of sediment core RHS-KS65; b) Rhone turbiditic valley and thalweg with close-up view at the position of sediment core RHSKS67. The reds lines outline the seismic reflectors in the turbiditic deposits.

Figure 5: Distribution of lithofacies and evolution of the sediment grain size (median) in sediment cores RHS-KS65 and RHS-KS67.

Figure 6a: Sedimentary lithofacies identified in sediment cores RHS-KS65 and RHS-KS67. Lithofacies 1 to 3 are interpreted as pelagic and hemipelagic lithofacies, they are present on both cores. Lithofacies 4 (a to c) are interpreted as turbiditic and are only present in sediment core RHS-KS67. A) photography, B) radiography, C) lithofacies, median grain-size (D50). The key of lithofacies is shown on Fig. 5 and described in detail in Tab. 4. 3 Open circles show the location of samples analysed for grain-size distribution.

Figure 6b: Turbiditic lithofacies with reverse then normal grading within thick $(3-8 \mathrm{~cm})$ beds, suggesting a hyperpycnal origin. A) photography, B) radiography, C) lithofacies, median 
grain-size (D50) and particle diameter. Open circles show the location of samples analysed for grain-size distribution.

Figure 7: Foraminifera relative abundances (\%) versus depth in (a) core RHS-KS65 and (b) core RHS-KS67. Climatic events were determined in accordance with our age model based on correlation of oxygen isotopes with that obtained on core MD99-2346 (Melki et al., 2009).

Figure 8: Foraminiferal assemblages in the size fraction $>125 \mu \mathrm{m}$ in various lithofacies of core RHS-KS67. A) lithofacies 2, B) lithofacies 3, C) lithofacies 4b, D) lithofacies 4d. a) median grain size, b) relative abundance of foraminiferal tests, c) relative abundance of broken foraminiferal tests, d) $\mathrm{P} /(\mathrm{P}+\mathrm{B})$ ratio, representative of productivity. Open circles represent sampling intervals used for this characterisation.

Figure 9: a) oxygen isotopes of ice core GICC50 (Andersen et al., 2007), b) oxygen isotopes of Globigerina bulloides of core MD99-2346 from the Pyreneo-Languedocian Sedimentary Ridge (Melki et al. 2009) (black curve) and from the average of several cores from the Var turbidite ridge (Jorry et al. 2011) (orange curve), c) oxygen isotopes of G. bulloides from core RHS-KS65, blue stars and numbers indicate calibrated radiocarbon dates d) oxygen isotopes of $G$. bulloides from core RHS-KS67, blue stars and numbers indicate calibrated radiocarbon dates e) Linear Sedimentation Rates (LSR) on cores RHS-KS65 (red curve) and RHS-KS67 (blue curve), frequency of turbidites in core RHS-KS67 by interval of $250 \mathrm{yrs}$ : blue bars for layers > 1mm ("beds"), red bars for layers < $1 \mathrm{~mm}$ ("laminae"). LGM: Last Glacial Maximum, HS 1: Heinrich Stadial 1, B/A: Bølling-Allerod, and YD: Younger Dryas.

Figure 10: Close up view of characteristics of turbidites in core RHS-KS67 between 20 and 16 cal. ka BP: a) thickness of the coarse terms of the turbidites (black curve: all analyses, red curve: average by intervals of $250 \mathrm{yrs}$ ), b) median (D50) grain size at the base of the coarse bed of turbidites (black curve: all data, red curve: average by intervals of $250 \mathrm{yrs}$ ), c) Linear Sedimentation Rates (LSR) (blue curve); d) frequency of turbidites by interval of 250 yrs: blue bars represent the frequency of "bed" turbidites (thickness $>1 \mathrm{~mm}$ ), red bars represent the frequency of laminae (thickness $\leq 1 \mathrm{~mm}$ ). LGM: Last Glacial Maximum, HS 1: Heinrich Stadial 1.

Figure 11: Correlation of the turbiditic record in the Rhone Turbidite System (core RHSKS67) with: a) Relative Sea Level (Clark et al., 2009), and various parameters in the Rhone watershed: b) Fluctuation of Swiss and Rhone glaciers extension, (in Jorry et al., 2011), adapted from Ivy-Ochs et al. (2008), c) Mean sediment load of the Rhone River by intervals 
of 200 yrs normalized to the present mean annual load (Kettner and Syvitski, 2009), d) Linear Sedimentation Rates (LSR) in the Rhone turbiditic valley (core RHS-KS67), e) Median grain size at the base of the coarse terms of turbidites in core RHS-KS67, f) frequency of turbidites in the Rhone turbiditic valley (core RHS-KS67).

Figure 12: Schematic evolution of the routing of the Rhone River sediment onto the shelf, canyon and turbidite system since the Last Glacial Maximum. (1) LGM: high sediment flux from the Rhone River and the sea-level lowstand (120 - $130 \mathrm{~m}$ below present-day) allowed the direct connection with the Petit Rhone canyon and favoured the deposition of hyperpycnites, 2) after the "19 ka" meltwater pulse (mwp19ka), between 19.5 and 18.5 cal. ka BP (Clark et al., 2012; Hanebuth et al., 2000), the Rhone River mouth was disconnected from the Petit Rhone canyon; the sediment input into the Rhone Turbidite System decreased despite a still high sediment load of the Rhone River (Kettner and Syvitski, 2009). Trigger mechanisms of turbidites were controlled by slope failures near the canyon head, 3) after ca. 18 cal. ka BP, due to the sea level rise, the depot centre shifted landward and the canyon head became starved of sediments; the turbiditic activity stopped in the Rhone Turbidite System. 


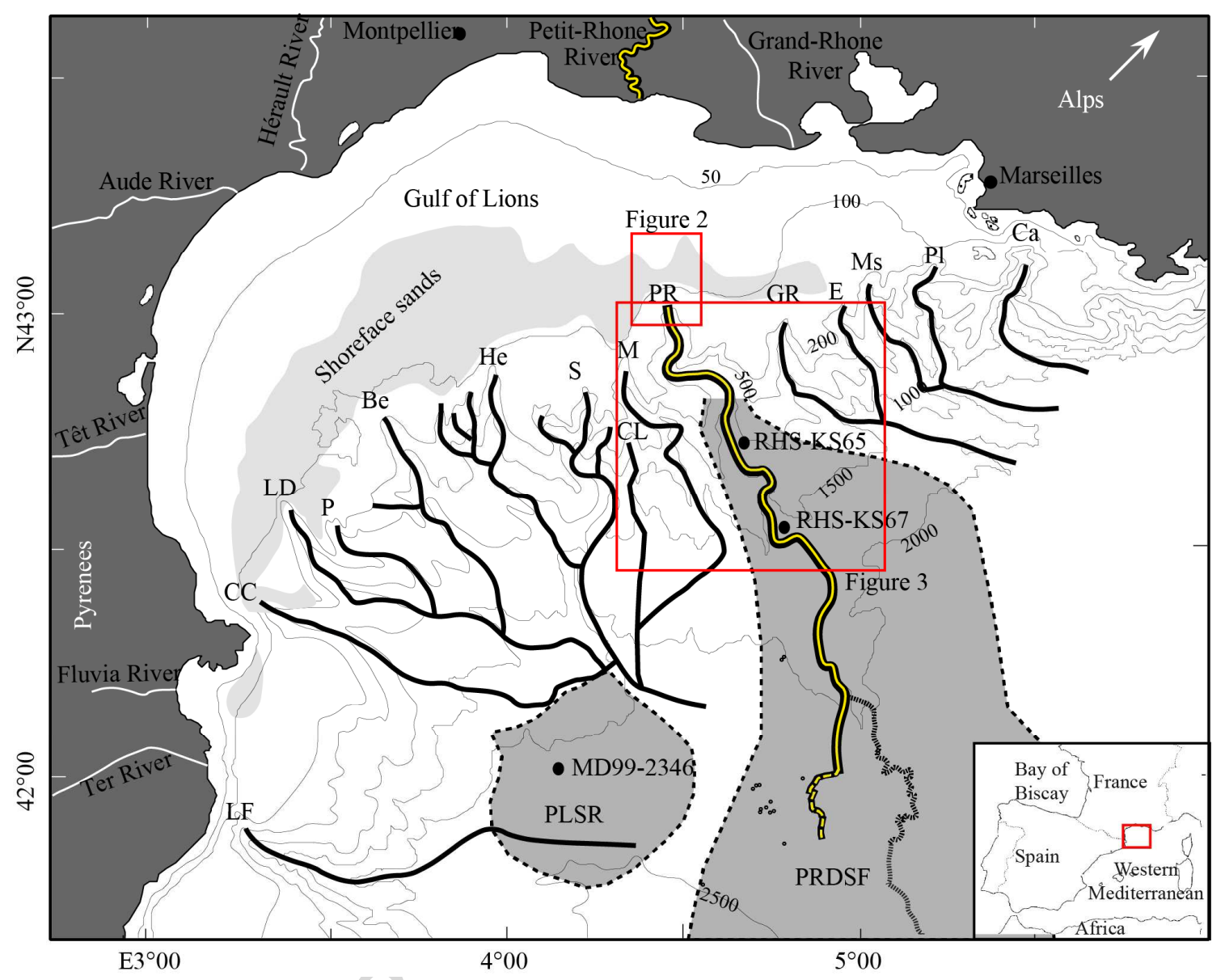

Figure 1 


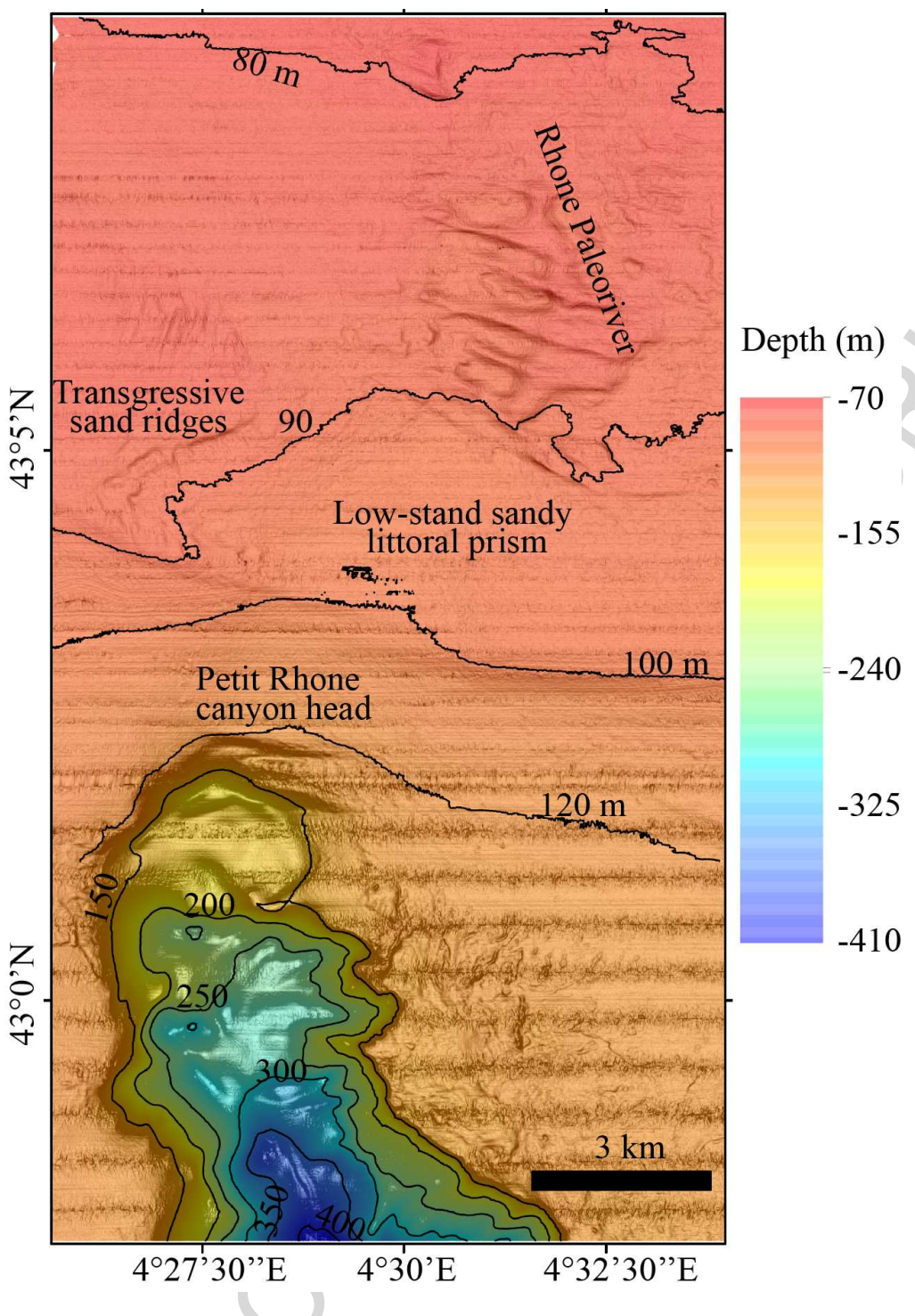

Figure 2 


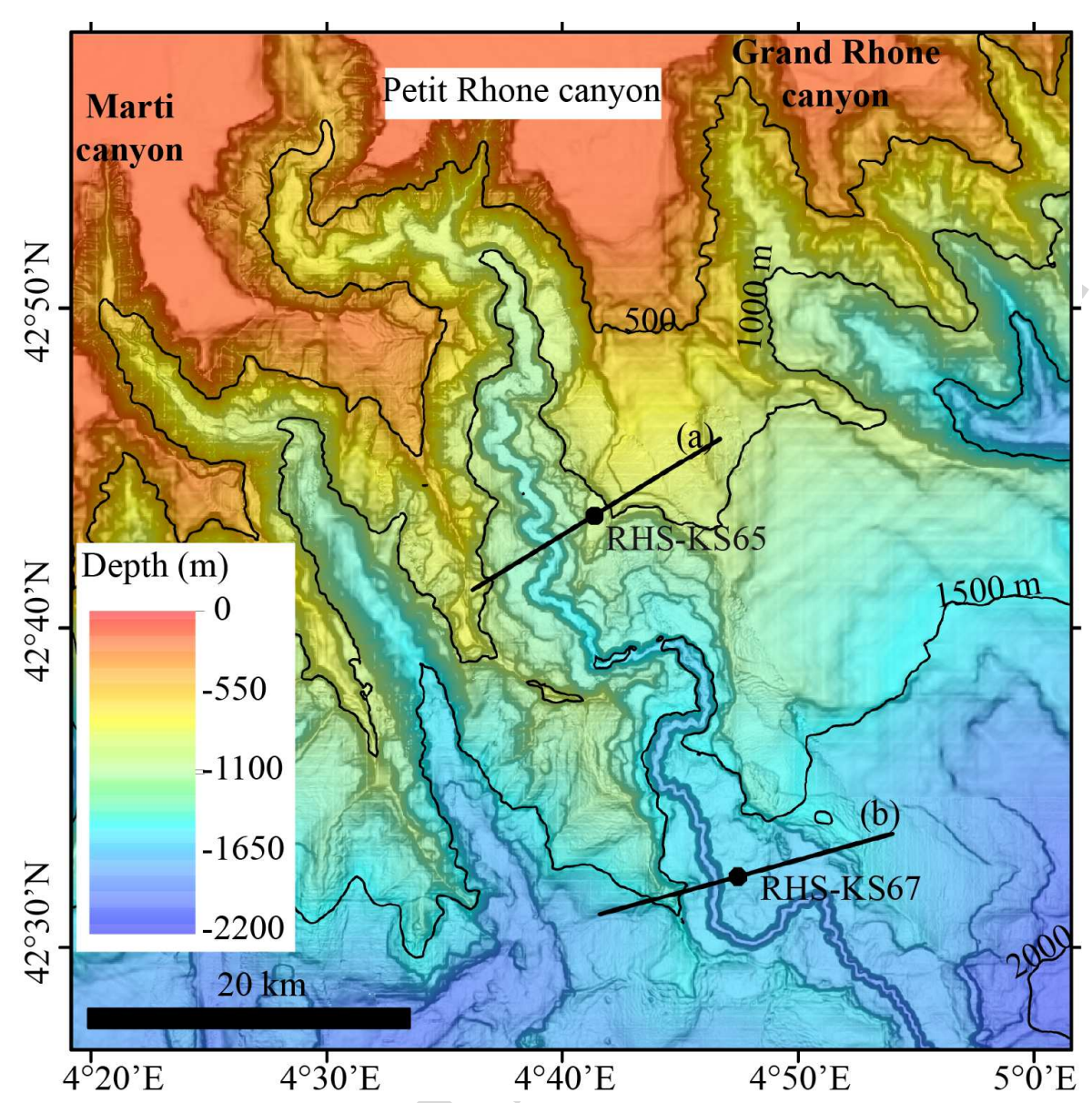

Figure 3 

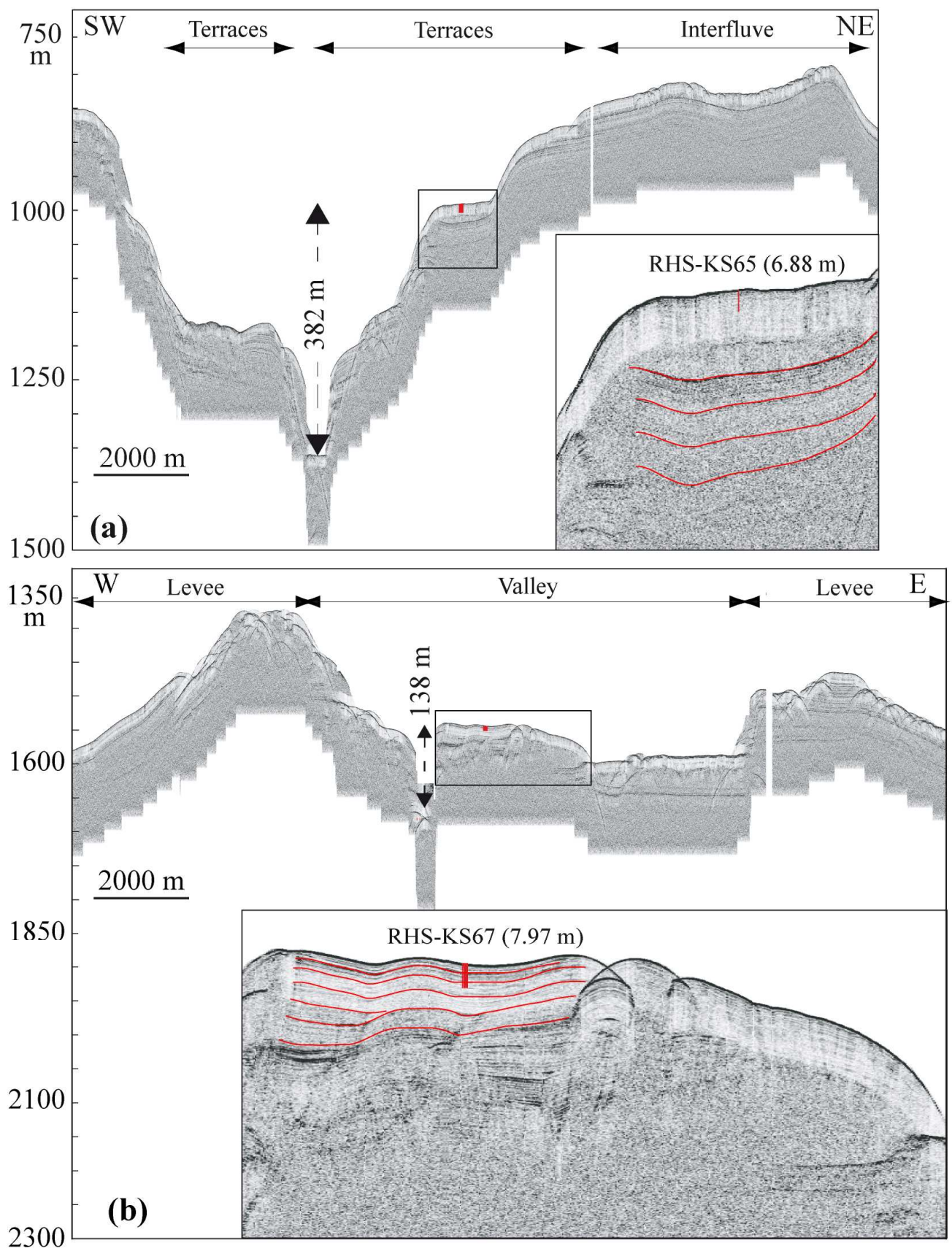

Figure 4 


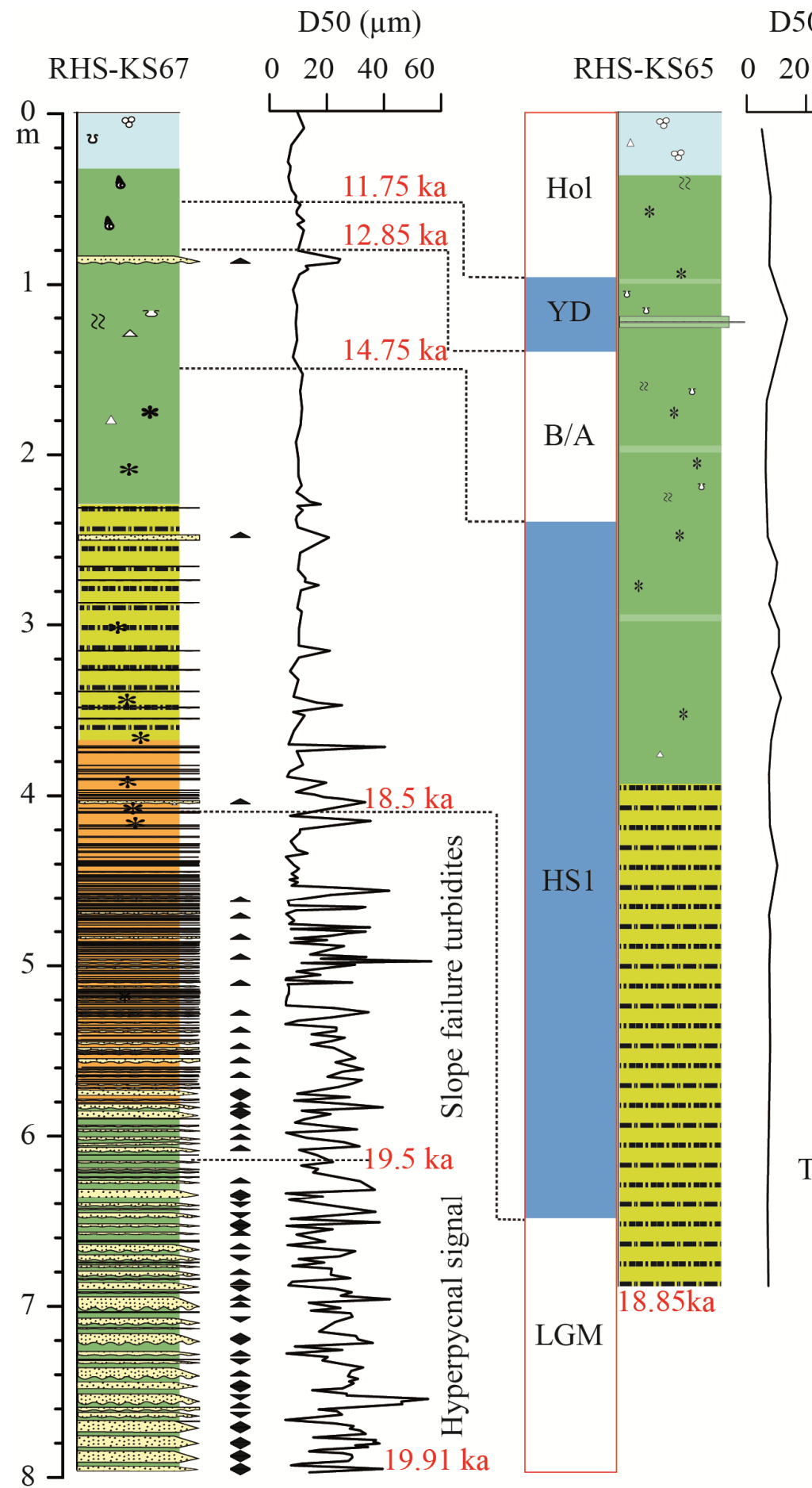

D50 $(\mu \mathrm{m})$

$40 \quad 60$ 

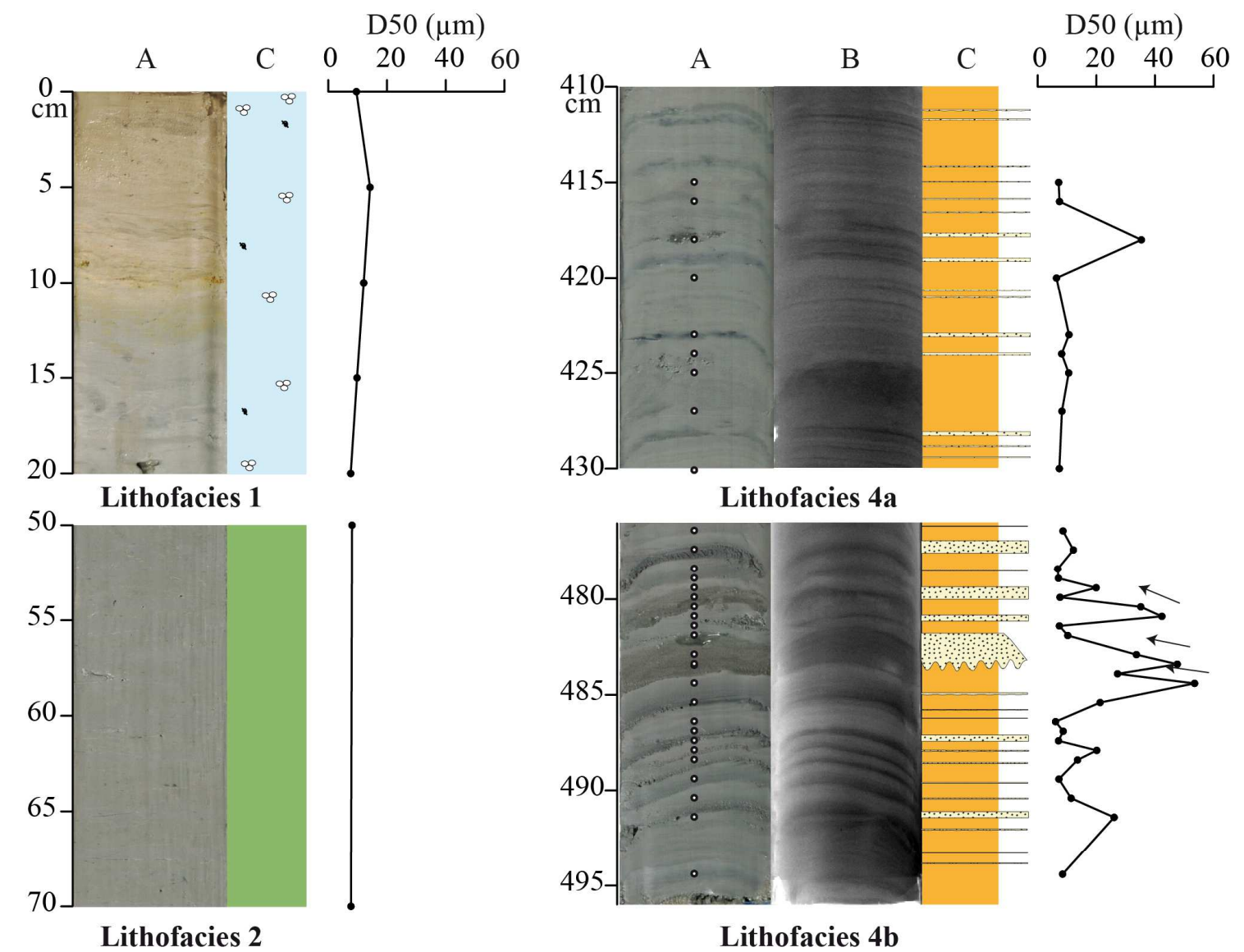

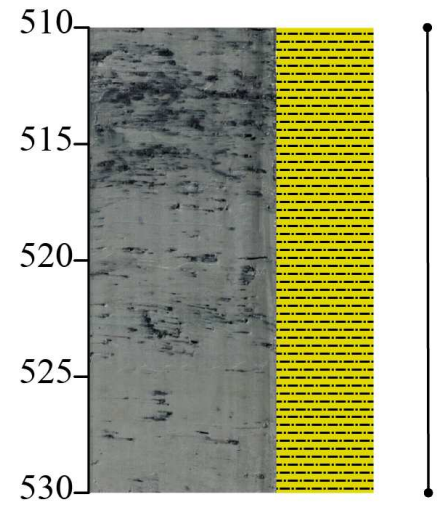

Lithofacies 3
Lithofacies $\mathbf{4 b}$

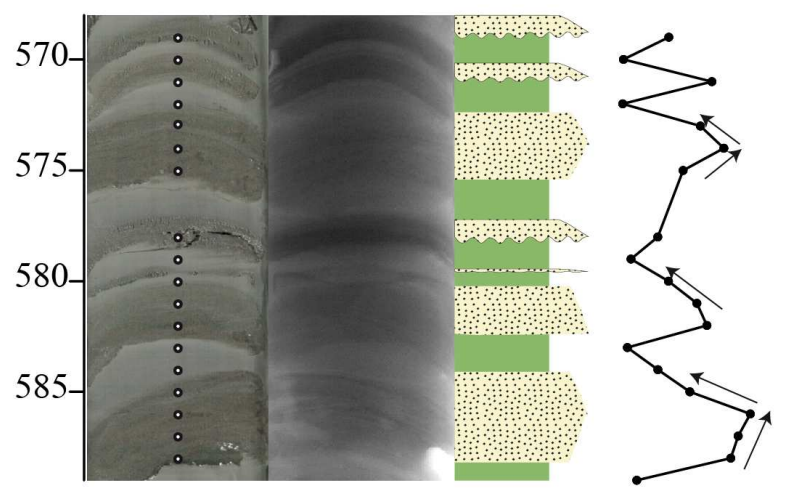

Lithofacies $4 c$

Figure 6a 


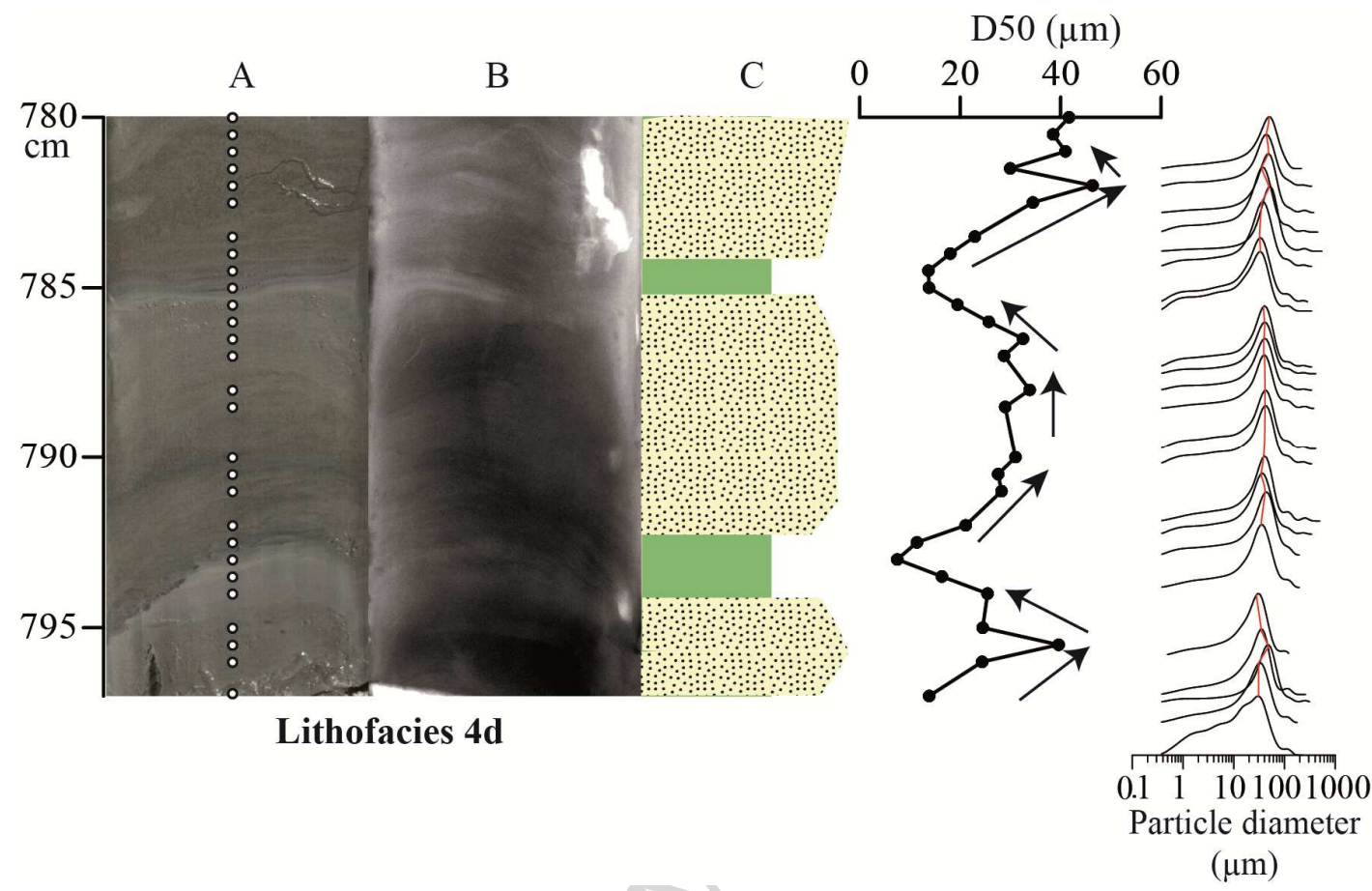

Figure $6 b$ 


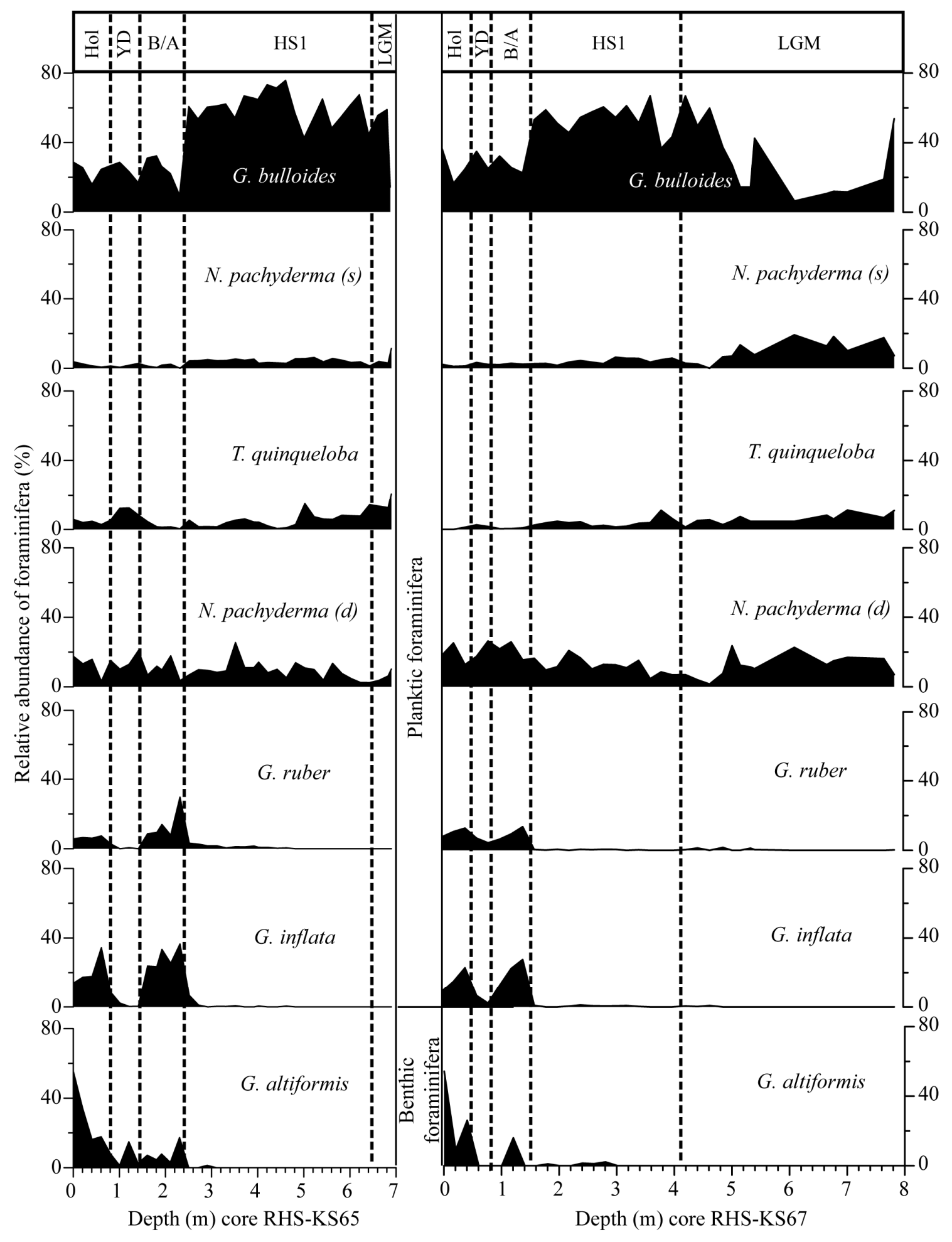

Figure 7 


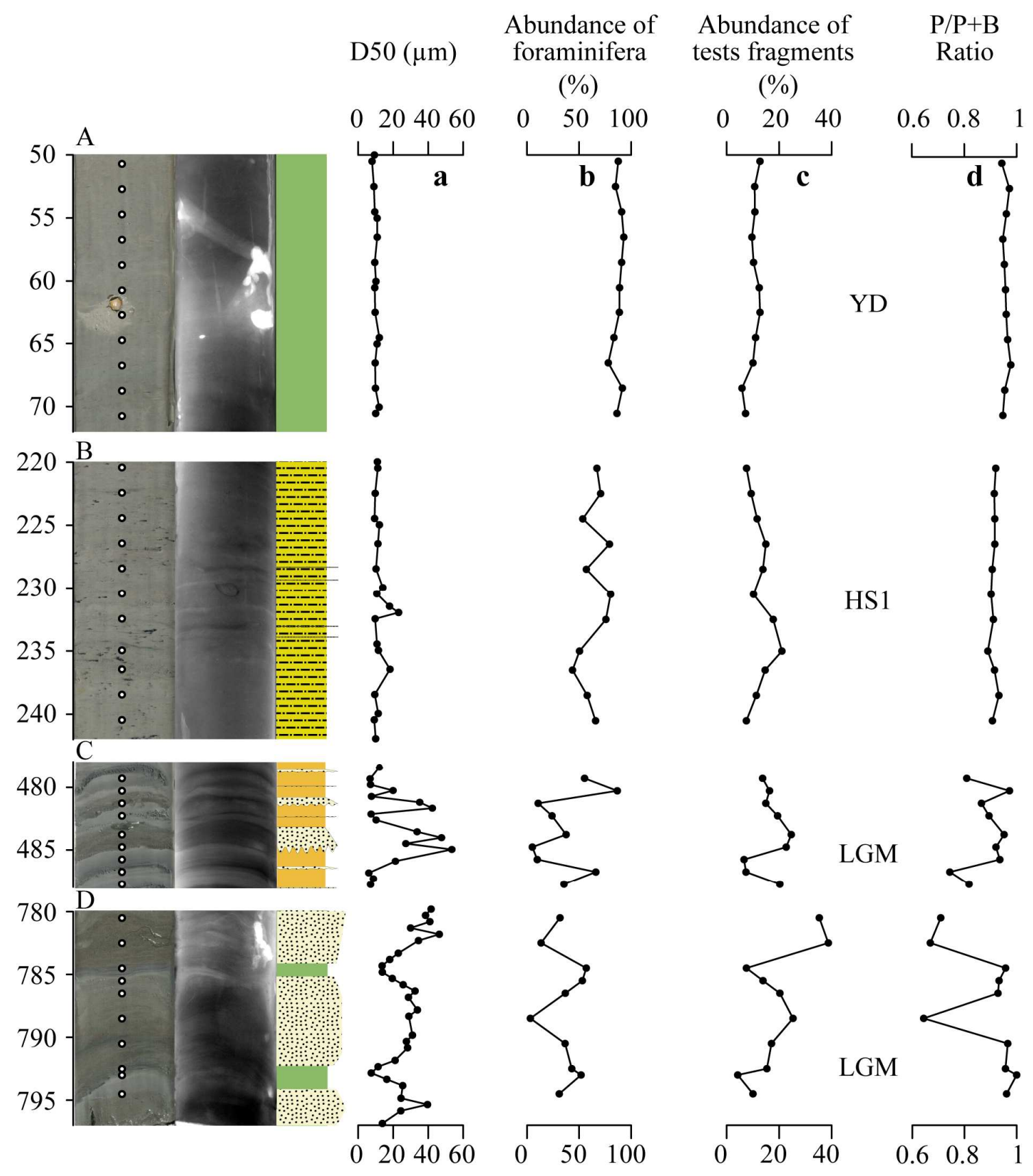

Figure 8 


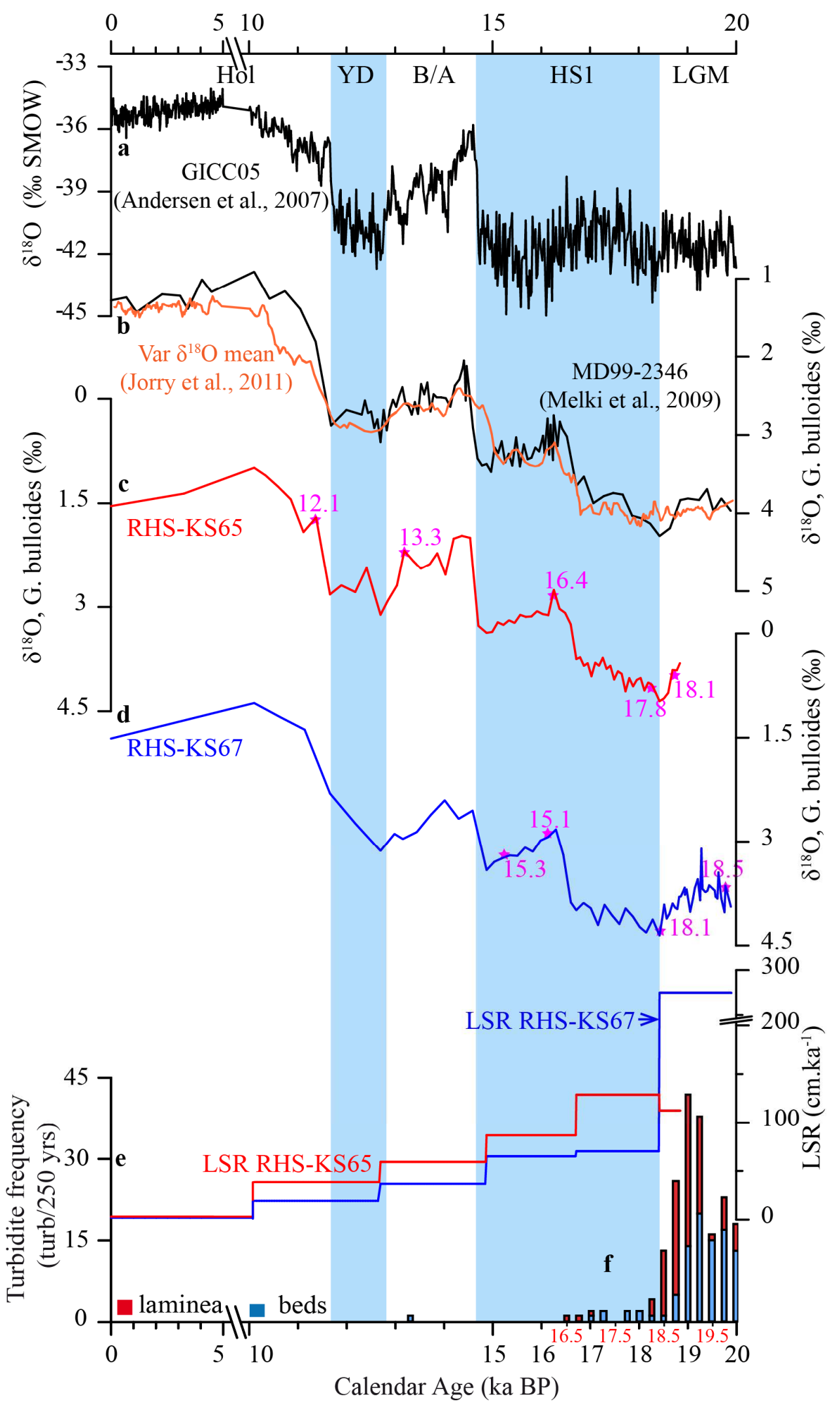

Figure 9 


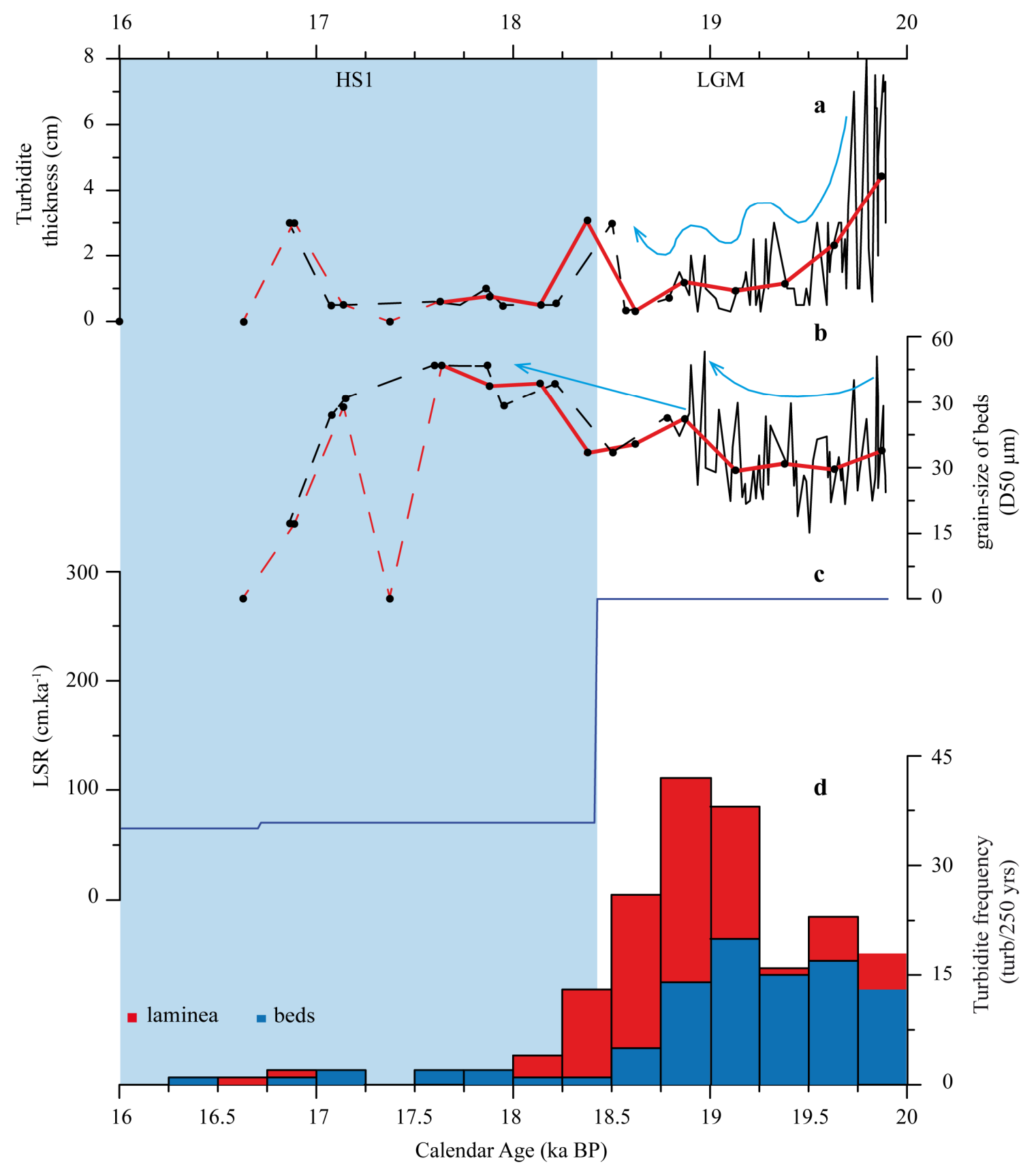

Figure 10 

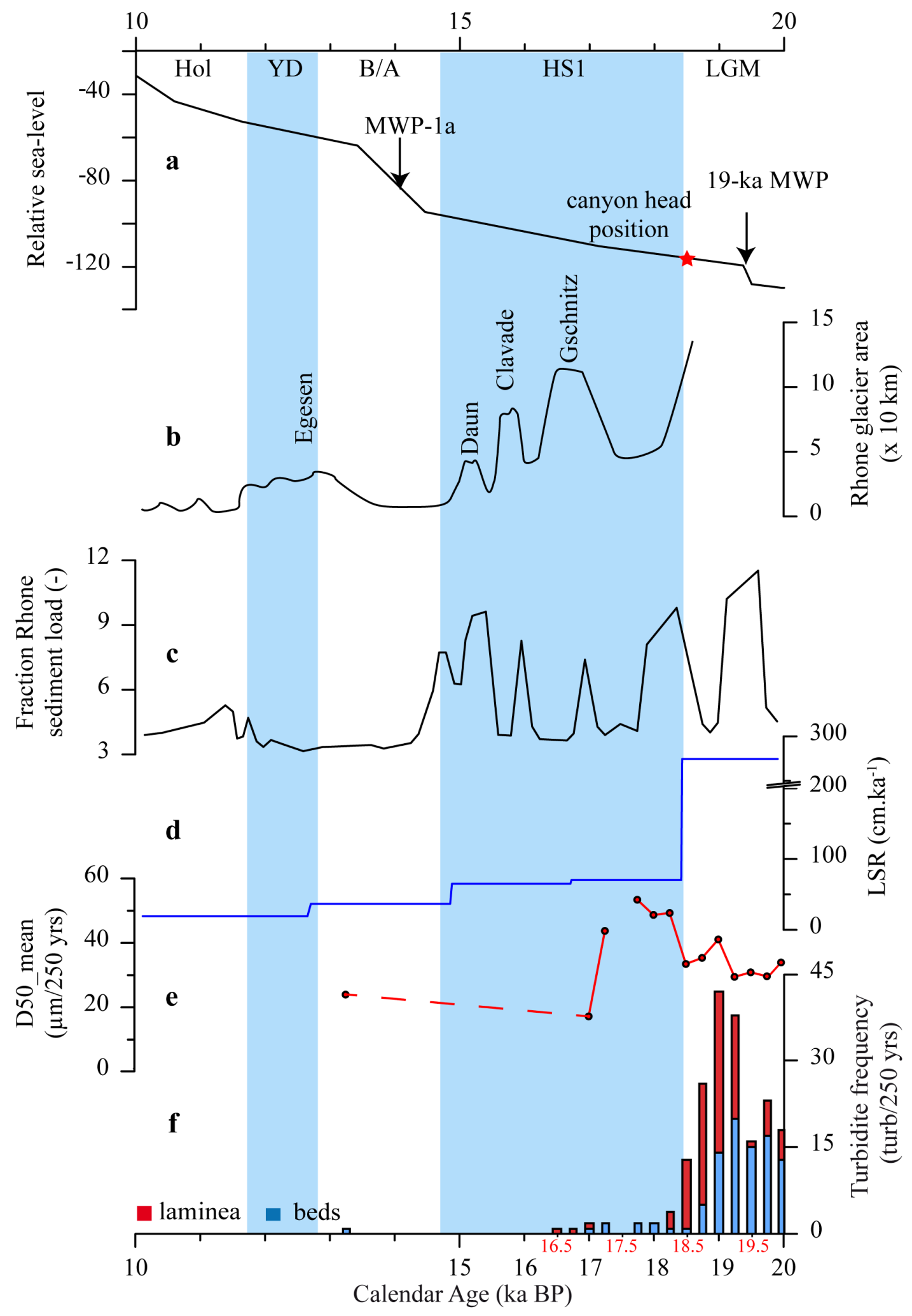

Figure 11 


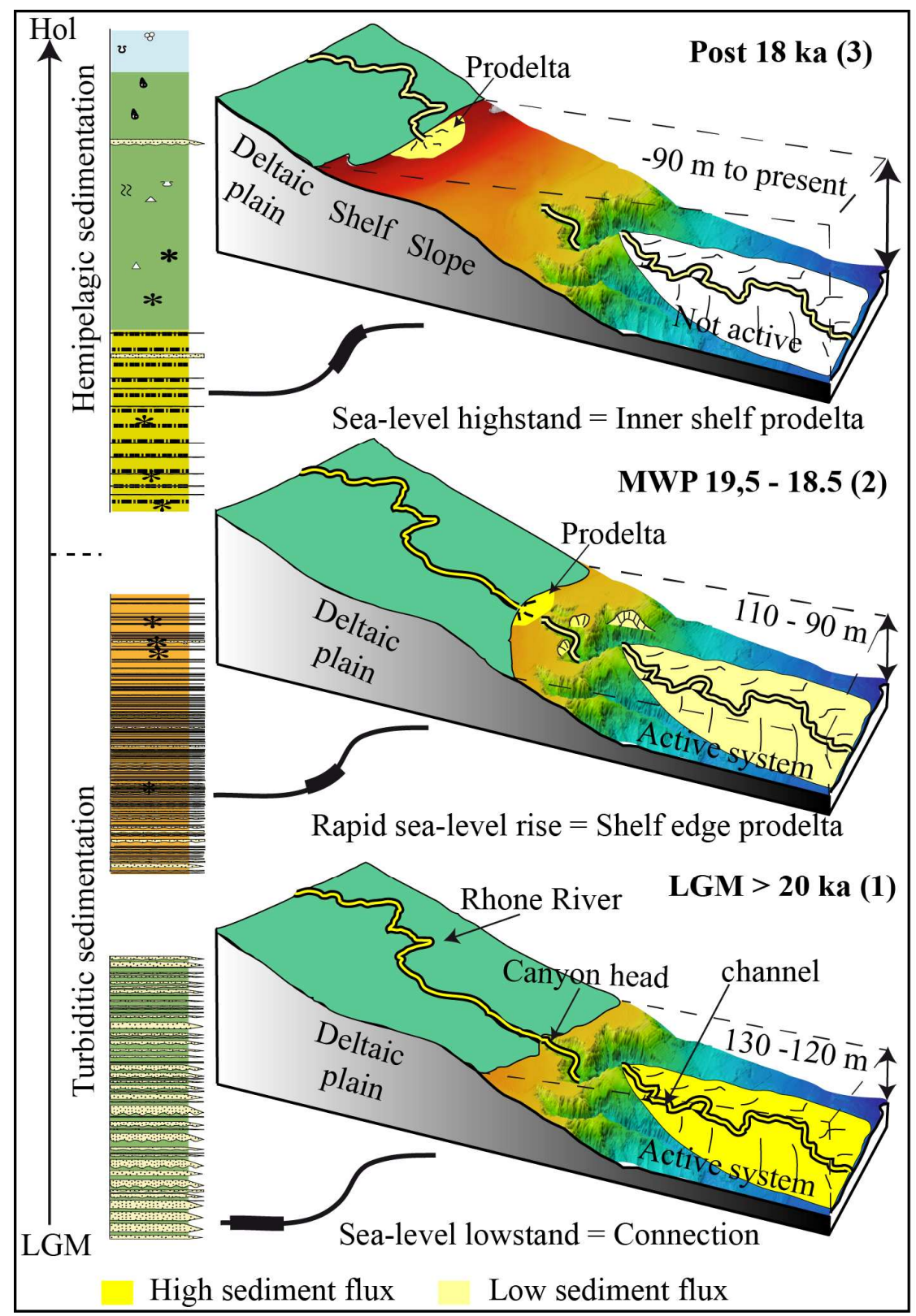

Figure 12 
Table 1

\begin{tabular}{ccccccc}
\hline Core label & Latitude & Longitude & $\begin{array}{c}\text { Water } \\
\text { depth }(\mathrm{m})\end{array}$ & $\begin{array}{c}\text { Length } \\
(\mathrm{m})\end{array}$ & Location & Cruise \\
\hline RHS-KS65 & $\mathrm{N} 42^{\circ} 43.489$ & $\mathrm{E} 004^{\circ} 41.369$ & 1010 & 6.95 & Terrace in canyon & RHOSOS \\
RHS-KS67 & $\mathrm{N} 42^{\circ} 32.216$ & $\mathrm{E} 004^{\circ} 47.445$ & 1566 & 7.97 & Turbidites valley & RHOSOS \\
MD99-2346 & $\mathrm{N} 42^{\circ} 02.610$ & E004 09.040 & 2100 & 10.61 & PLSR & MD114- \\
IMAGES V \\
\hline
\end{tabular}

Table 2

\begin{tabular}{|c|c|c|c|c|c|c|}
\hline $\begin{array}{l}\text { Core } \\
\text { label }\end{array}$ & $\begin{array}{l}\text { Depth } \\
(\mathrm{cm})\end{array}$ & $\begin{array}{l}\text { Laboratory } \\
\text { number }\end{array}$ & $\begin{array}{c}\text { Corrected 14C age } \\
(\mathrm{yr} \mathrm{BP})\end{array}$ & $\begin{array}{c}2 \sigma \text { cal. BP age } \\
\text { range }(y r)\end{array}$ & $\begin{array}{c}\text { Cal BP average } \\
\text { age }(\mathrm{yr})\end{array}$ & Dated material \\
\hline \multirow{5}{*}{ 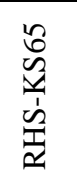 } & $80-81$ & SacA-15958 & $10600 \pm 40$ & $11870-12318$ & 12099 & G. bulloides \\
\hline & $160-161$ & SacA-15960 & $11825 \pm 40$ & $13190-13405$ & 13297.5 & G. bulloides \\
\hline & $380-381$ & SacA-23219 & $13965 \pm 50$ & $16145-16557$ & 16351 & G. bulloides \\
\hline & $610-611$ & SacA-15959 & $15020 \pm 60$ & $17608-17980$ & 17794 & G. bulloides \\
\hline & $687-688$ & SacA-23218 & $15330 \pm 50$ & $17954-18317$ & 18135.5 & G. bulloides \\
\hline \multirow{4}{*}{$\begin{array}{l}\hat{0} \\
\tilde{n} \\
\underline{1} \\
\tilde{n} \\
\underline{1} \\
\simeq\end{array}$} & $170-171$ & SacA-23220 & $13215 \pm 45$ & $15102-15469$ & 15285.5 & G. bulloides \\
\hline & $230-231$ & SacA-23221 & $13105 \pm 45$ & 14 917-15 296 & 15106.5 & G. bulloides \\
\hline & $380-381$ & SacA-23222 & $15310 \pm 90$ & 17 969-18 297 & 18133 & G. bulloides \\
\hline & 784-785 & Poz-56260 & $15640 \pm 90$ & 18 285-18 720 & 18502.5 & $\begin{array}{l}\text { Bulk planktonic } \\
\text { foraminifera }\end{array}$ \\
\hline
\end{tabular}

Table 3

\begin{tabular}{cccccc}
\hline Depth $(\mathrm{cm})$ & $\begin{array}{c}\text { Laboratory } \\
\text { number }\end{array}$ & $\begin{array}{c}\text { Corrected 14C } \\
\text { age }(\mathrm{yr} \text { BP) }\end{array}$ & $\begin{array}{c}2 \sigma \text { cal. BP age } \\
\text { ranges }(\mathrm{yr})\end{array}$ & $\begin{array}{c}\text { Cal BP average } \\
\text { age }(\mathbf{y r})\end{array}$ & Dated material \\
\hline $30-31$ & LLNL-87498 & $3535 \pm 30$ & $3340-3513$ & $\mathbf{3 4 2 6 . 5}$ & G. bulloides \\
$46-47$ & ARTEMIS-1258 & $4830 \pm 50$ & $4963-5277$ & $\mathbf{5 1 2 0}$ & G. bulloides \\
$155-156$ & ARTEMIS-1259 & $11120 \pm 70$ & $12526-12764$ & $\mathbf{1 2 ~ 6 4 5}$ & G. bulloides \\
$210-211$ & ARTEMIS-1260 & $12010 \pm 70$ & $13301-13641$ & $\mathbf{1 3 4 7 1}$ & G. bulloides \\
$280-281$ & LLNL-87500 & $12370 \pm 35$ & $13723-13982$ & $\mathbf{1 3 ~ 8 5 2 . 5}$ & G. bulloides \\
$340-341$ & LLNL-87501 & $13025 \pm 35$ & $14768-15170$ & $\mathbf{1 4 9 6 9}$ & G. bulloides \\
$370-371$ & LLNL-87502 & $13295 \pm 45$ & $15201-15606$ & $\mathbf{1 5 4 0 3 . 5}$ & G. bulloides \\
$435-436$ & ARTEMIS-1261 & $14010 \pm 90$ & $16118-16738$ & $\mathbf{1 6 4 2 8}$ & G. bulloides \\
$499-500$ & ARTEMIS-1369 & $14700 \pm 80$ & $17139-17641$ & $\mathbf{1 7 3 9 0}$ & G. bulloides \\
$579-580$ & ARTEMIS-1262 & $16330 \pm 110$ & $18933-19512$ & $\mathbf{1 9 2 2 2 . 5}$ & G. bulloides \\
$690-692$ & LLNL-87503 & $17820 \pm 45$ & $20823-21238$ & $\mathbf{2 1 ~ 0 3 0 . 5}$ & G. bulloides \\
$748-749$ & ARTEMIS-1263 & $18400 \pm 130$ & $21430-22194$ & $\mathbf{2 1 ~ 8 1 2}$ & G. bulloides \\
$880-881$ & ARTEMIS-1264 & $20750 \pm 150$ & $24056-24980$ & $\mathbf{2 4 ~ 5 1 8}$ & N. pachyderma s. \\
\hline
\end{tabular}


Table 4

\begin{tabular}{|c|c|c|c|c|c|c|c|c|}
\hline \multirow[b]{2}{*}{$\begin{array}{l}\text { Lithofacie } \\
\text { s number }\end{array}$} & \multirow[b]{2}{*}{$\begin{array}{l}\text { Grain- } \\
\text { size D50 } \\
(\mu \mathrm{m})\end{array}$} & \multirow[b]{2}{*}{$\begin{array}{l}\text { Colour and } \\
\text { composition }\end{array}$} & \multirow[b]{2}{*}{$\begin{array}{c}\text { Sedimentary } \\
\text { structures } \\
\text { and } \\
\text { observations }\end{array}$} & \multirow[b]{2}{*}{$\begin{array}{c}\mathrm{LS} \\
\mathrm{R}\end{array}$} & \multirow[b]{2}{*}{$\begin{array}{c}\text { Lithofacies } \\
\text { type }\end{array}$} & \multicolumn{3}{|c|}{$\begin{array}{c}\text { Correspondence to other } \\
\text { classification }\end{array}$} \\
\hline & & & & & & $\begin{array}{c}\text { Bouma } \\
(1962) \\
\text { Shanmuga } \\
\text { m (2000) }\end{array}$ & $\begin{array}{c}\text { Stow } \\
\text { and } \\
\text { Piper } \\
(1984 \\
\text { ) }\end{array}$ & $\begin{array}{c}\text { RTS } \\
\text { (Dennielo } \\
\text { u et al } \\
2006, \\
2009 \text { ) }\end{array}$ \\
\hline 1 & $<15$ & $\begin{array}{c}\text { Brownish } \\
\text { silty-clay, } \\
\text { abundant } \\
\text { foraminifera } \\
\text { and } \\
\text { calcareous } \\
\text { nannoplancto } \\
\text { n }\end{array}$ & $\begin{array}{c}\text { Homogeneou } \\
\text { s and } \\
\text { bioturbated }\end{array}$ & 4 & & $\mathrm{Te}$ & $\mathrm{F}$ & $\begin{array}{l}\text { Facies } 1 \\
(2009)\end{array}$ \\
\hline 2 & $<15$ & $\begin{array}{c}\text { Light-gray } \\
\text { silty-clay } \\
\text { abundant } \\
\text { foraminifera } \\
\text { and } \\
\text { calcareous } \\
\text { nannoplancto } \\
\text { n }\end{array}$ & $\begin{array}{c}\text { Homogeneou } \\
\text { s and } \\
\text { bioturbated }\end{array}$ & $\begin{array}{l}20 \\
\text { to } \\
40\end{array}$ & $\begin{array}{l}\text { Pelagic to } \\
\text { hemipelagi } \\
\text { c }\end{array}$ & $\mathrm{Te}$ & F/E3 & $\begin{array}{c}\text { Facies } 2 \\
(2009)\end{array}$ \\
\hline 3 & $7-15$ & $\begin{array}{c}\text { Dark-grey } \\
\text { mud with } \\
\text { foraminifera } \\
\text { and } \\
\text { calcareous } \\
\text { nannoplancto } \\
\text { n and } \\
\text { abundant } \\
\text { black specks } \\
\text { (sulphur) }\end{array}$ & $\begin{array}{l}\text { Discontinuou } \\
\text { s laminae of } \\
\text { black specks; } \\
\text { few } \\
\text { discontinuou } \\
\text { s silt laminae }\end{array}$ & $\begin{array}{l}71 \\
\text { to } \\
125\end{array}$ & $\begin{array}{l}\text { Hemipelagi } \\
\text { c with } \\
\text { probable } \\
\text { pulses of } \\
\text { terrigenous } \\
\text { input }\end{array}$ & Te (T6-T8) & E2 & $\begin{array}{c}\text { Not } \\
\text { described }\end{array}$ \\
\hline \multirow{4}{*}{4} & $\begin{array}{c}20 \\
\text { (lamina } \\
\text { ) }\end{array}$ & $\begin{array}{c}\text { Dark gray } \\
\text { silty-clay } \\
\text { with silt } \\
\text { laminae }\end{array}$ & $\begin{array}{c}\text { Silt laminae } \\
\text { (ca. } 1 \\
\text { laminae/5 } \\
\mathrm{cm} \text { ) }\end{array}$ & & & $\begin{array}{c}\mathrm{Td}-\mathrm{Te} \\
(\mathrm{T} 3-\mathrm{T} 4)\end{array}$ & E1 & $\begin{array}{c}\text { Facies } 4 \\
(2006) \\
\text { and } \\
\text { Facies 5 } \\
(2009)\end{array}$ \\
\hline & $\begin{array}{c}20 \\
\text { (laminae } \\
\text { ) }\end{array}$ & $\begin{array}{l}\text { Dark grey } \\
\text { silty-clay } \\
\text { with } \\
\text { abundant } \\
\text { parallel and } \\
\text { regular silty } \\
\text { laminea, }\end{array}$ & $\begin{array}{l}\text { Silt laminae } \\
\quad(\text { ca. } 1 \\
\text { laminae/cm) }\end{array}$ & & $\begin{array}{c}\text { Turbiditic } \\
\text { with } \\
\text { possible } \\
\text { overlaying } \\
\text { hemipelagi }\end{array}$ & $\begin{array}{l}\mathrm{Td}-\mathrm{Te} \\
\text { (T3) }\end{array}$ & E1 & $\begin{array}{c}\text { Facies } 3 \\
(2006)\end{array}$ \\
\hline & $\begin{array}{l}20-40 \\
\text { (beds) }\end{array}$ & $\begin{array}{l}\text { Alternance of } \\
\text { dark gray } \\
\text { silty-clay and } \\
\text { dark grey } \\
\text { silty beds }\end{array}$ & $\begin{array}{c}\text { Silty-clay } \\
\text { layers } \\
\text { thicker than } \\
\text { silty beds }(1- \\
3 \mathrm{~cm}) . \\
\text { Silty beds } \\
\text { show normal } \\
\text { gradded }\end{array}$ & 270 & c & $\mathrm{Td}-\mathrm{Te}$ & $\begin{array}{c}\mathrm{E} 1 \\
\text { and } \mathrm{F}\end{array}$ & $\begin{array}{c}\text { Facies } 2 \\
(2006)\end{array}$ \\
\hline & $\begin{array}{c}20-55 \\
\text { (beds) }\end{array}$ & $\begin{array}{c}\text { Alternance of } \\
\text { dark gray } \\
\text { silty-clay } \\
\text { with dark }\end{array}$ & $\begin{array}{l}\text { Silty clay ca. } \\
1 \mathrm{~cm} \text { thick } \\
\text { Silty beds } \\
(\text { ca. } 3 \mathrm{~cm})\end{array}$ & & $\begin{array}{c}\text { Hyperpycn } \\
\text { al turbidites } \\
\text { with } \\
\text { possible }\end{array}$ & $\mathrm{Td}$ and $\mathrm{Te}$ & $\begin{array}{c}\text { E1 } \\
\text { and } F\end{array}$ & $\begin{array}{c}\text { Not } \\
\text { described }\end{array}$ \\
\hline
\end{tabular}


gray silty beds

can show reverse gradding overlaying

hemipelagi

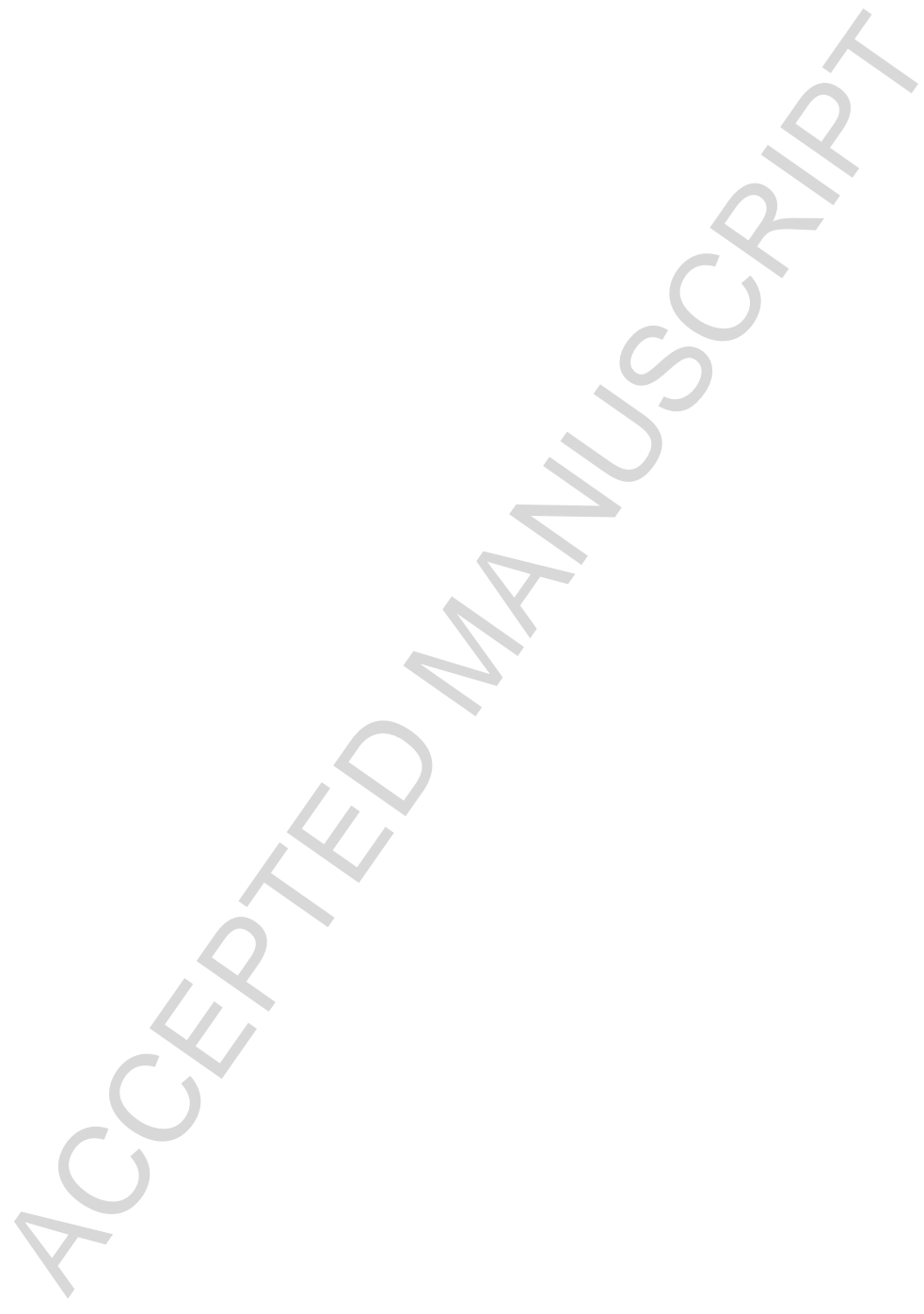


Table 5

\begin{tabular}{|c|c|c|}
\hline Core label & Depth $(\mathrm{cm})$ & Cal age (yr BP) \\
\hline \multirow{6}{*}{ 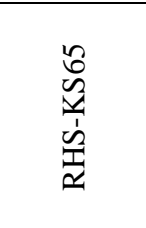 } & 31 & 10105 \\
\hline & 131 & 12699 \\
\hline & 260 & 14876 \\
\hline & 420 & 16719 \\
\hline & 640 & 18427 \\
\hline & 688 & 18854 \\
\hline \multirow{6}{*}{$\begin{array}{l}\hat{\sigma} \\
\mathscr{n} \\
\underline{1} \\
\tilde{n} \\
\underline{a}\end{array}$} & 20 & 10105 \\
\hline & 70 & 13699 \\
\hline & 150 & 14876 \\
\hline & 270 & 16719 \\
\hline & 390 & 18427 \\
\hline & 792 & 19891 \\
\hline
\end{tabular}


Table 6

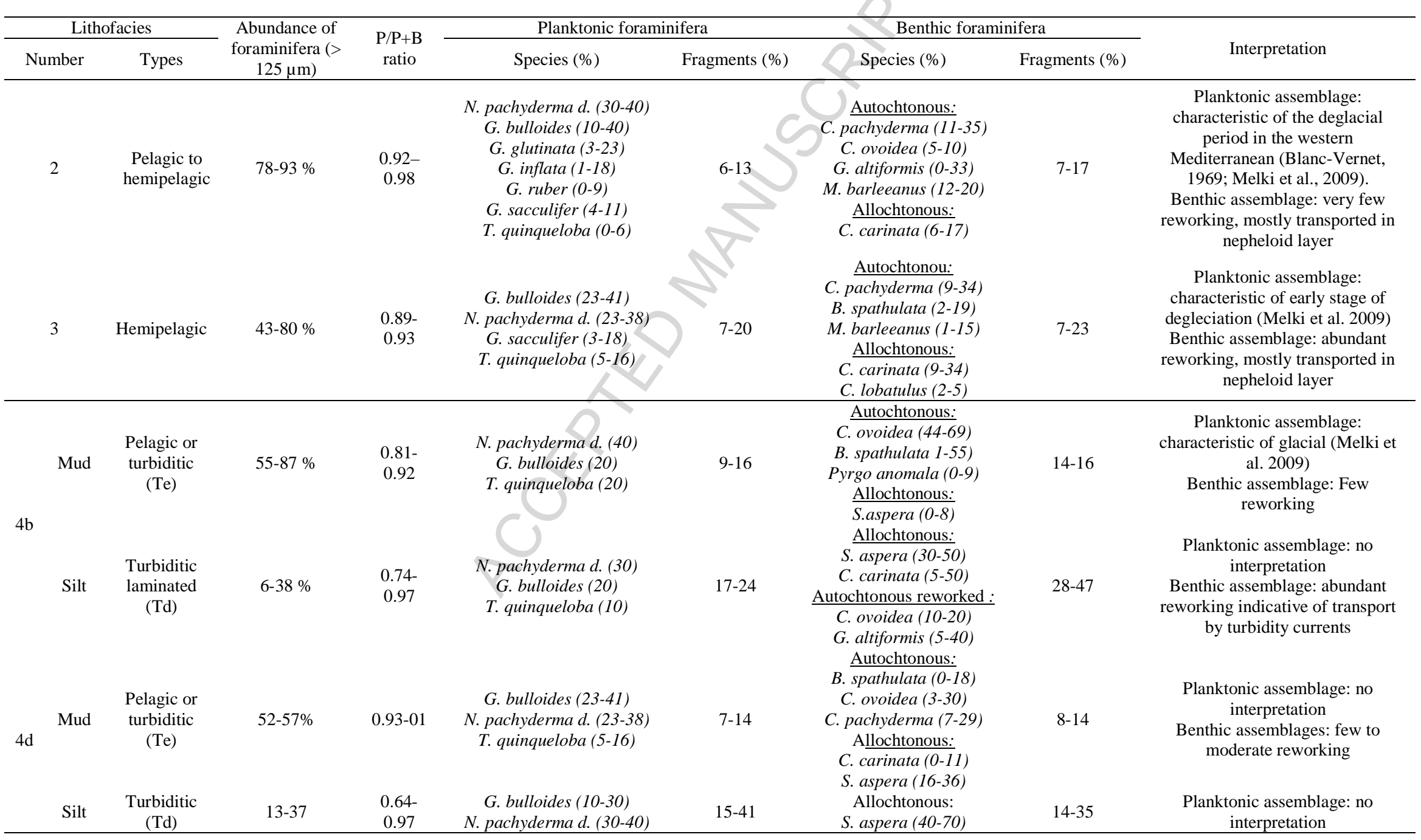


T. quinqueloba $(0-30)$

Elphidium spp (10-35)

Autochtonous reworked:
Benthic assemblage: Abundant reworking indicative of transport by turbidity currents 